Digitalizacja archiwalnych numerów czasopisma naukowego Analecta Cracoviensia 1-24 (1969-1992) i ich publikacja w otwartym dostępie - zadanie finansowane w ramach umowy 672/P-DUN/2017 ze środków Ministra Nauki i Szkolnictwa Wyższego przeznaczonych na działalność upowszechniającą naukę

ANALECT A CRACOVIENSIA 4 (1972) $147-179$

\title{
APOKALIPTYCZNA SZATA LITERACKA OPISÓW * PARUZJI CHRYSTUSA Z LISTÓW DO TESALONICZAN
}

\author{
WPROWADZENIE
}

Obraz paruzji Chrystusa ${ }^{1}$ naszkicowany jest w Listach do Tesaloniczan zasadniczo w trzech tekstach: 1 Tes 4, 13-18 oraz 2 Tes 1, 6-10 i 2, 1-14. Warto uwzględnić też tekst 1 Tes $1,9^{\mathrm{b}}-10^{2}$. ,Tworzywem” tego obrazu są stwierdzenia następujące ${ }^{3}$ :

1. Zmarli w Chrystusie powstaną z martwych na rozkaz - na głos Archanioła czyli 〈na głos〉 trąby Bożej (1 Tes 4, 16).

2. Pan zstąpi, objawi się $z$ nieba (1 Tes 1,10 i 4,16 oraz 2 Tes 1,7 ), $z$ aniołami swej mocy (2 Tes 1,7$), w$ ptonacym ogniu (2 Tes 1,8$)$.

3. Żywi - wraz z tymi, którzy umarli w Chrystusie i teraz zmartwychwstali - zostaną porwani na spotkanie Pana w obłokach, w przestworza (1 Tes 4, 17).

4. „Bezbożnika” zaś zmiecie Pan Jezus precz tchnieniem ust swoich (2 Tes 2, 8).

* Przedstawiona praca jest skrótem mojej rozprawy doktorskiej, pisanej w Krakowie. Nosiła ona tytuł: Dzień paruzji Chrystusa według Listów do Tesaloniczan: obraz - a treść teologiczna. Promotorem jej był O. Prof. Augustyn Jankcwski OSB. Ku niemu też kieruję wyrazy mojej szczególnej wdzięczności. Za danie mi czasu na prace badawcza dziękuję O. Placydowi Galińskiemu OSB, Opatowi tynieckiemu, mojemu Przełożonemu. Księżom Profesorom Stanisławowi Grzybkowi, Kazimierzowi Romaniukowi, Heinzowi Schürmannowi i Wolfgangowi Trillingowi dziękuję za cenne uwagi krytyczne dotyczące mojej rozprawy, uwagi, które ułatwiły mi jej ostateczną redakcję.

1 W pracy tej nie zajmujemy się wydarzeniami, które mają poprzedzić dzień paruzji, które są jego prodromami. Interesują nas jedynie wydarzenia samego „dnia Pańskiego".

2 Można by tutaj wymienić jeszcze krótkie wypowiedzi z 1 Tes 2, 16. 19; 3, 13.

3 Podajemy je od razu w przekładzie własnym. 
Komentator Listów do Tesaloniczan B. Rigaux stawia pytanie, czy te elementy składające się na obraz paruzji są jedynie ozdobnikami tekstu apokaliptyczną szatą literacką, która wprowadza tylko pożądany nastrój tajemniczości - czy też kryje się za nimi jakaś rzeczywistość, jakaś treść teologiczna: ,jak przedmiot w opakowaniu" "4. Pytanie to pozostawia bez odpowiedzi.

Przed kilku laty zostało ono podjęte przez R. Schnackenburga. Wnikliwy ten egzegeta i teolog nie negując waloru literackiego apokaliptycznej symboliki, która rzeczywiście wprowadza nastrój tajemniczości, stawia ogólną tezę: za elementami apokaliptycznej szaty literackiej kryje się nie zawsze dostrzegana dotąd treść teologiczna. Toteż „trzeba włożyć jeszcze wiele wysiłku - pisze - żeby treść obietnic i pouczeń odnoszących się do paruzji Chrystusa, wyrażoną w trudnych obrazach i symbolach, odczytać dzisiaj poprawnie. Trzeba teologicznie dopracować znaczenie tych obrazów i symboli. Zadania tego - dodaje - właściwie nikt się dotychczas nie podjął" 5 .

Podejmując wskazane zadanie w ramach tej ograniczonej objętościowo pracy, przyjmujemy następujące założenia metodologiczne:

a) Opieramy się na tekście ustalonym zbiorowo przez kontynuatorów dzieła K. Alanda ${ }^{6}$.

b) W przekładach tekstów staramy się o jak największą wierność względem tekstu oryginalnego. Słowa umieszczane w nawiasach trójkątnych ułatwiają szybsze zrozumienie treści - mogą być jednak opuszczone bez większej szkody dla składni zdań.

c) Skoro jest rzeczą bezsporną, że oba Listy do Tesaloniczan są dziełem kogoś, kto widzi prawdy dotyczące zbawienia dokonywanego przez Chrystusa na tle proroctw $S T$ - i skoro jest rzeczą bezsporną, że oba Listy są $\mathrm{w}$ równej mierze pismami kanonicznymi — traktujemy je jako jedną sensowną całość. Pozostawiamy nie tkniętą sprawę Pawłowego autorstwa 2 Tes $^{7}$, salvo iudicio meliore o różnych autorach obu Listów ${ }^{8}$.

4 Les Epîtres aux Théssaloniciens, Paris 1956, 525.

5 Neutestamentliche Theologie - der Stand der Forschung, Leipzig 1969, 139.

6 K. Aland, M. Black, B. M. Metzger, A. Wikgren, The Greek New Testament, London 1966.

7 Zob. J. Stępień, Problem wzajemnego stosunku literackiego Listów do Tesaloniczan $i$ próby jego rozwiazania, "Ruch Biblijny i Liturgiczny" (cyt. dalej: RuBib) 13 (1960) 414-435. Tenże, Autentyczność Listów do Tesaloniczan, „Collectanea Theologica" (cyt. dalej: ClctnTh) 34 (1963) 91-180. 1972 .

${ }_{8}$ Zob. W. Trilling, Untersuchungen zum Zweiten Thessalonicherbrief, Leipzig 
C z ęść pierwsza

\section{PRZEKŁAD TEKSTÓW - PARUZJA JAKO „DZIEŃ GNIEWU” I "DZIEŃ \\ ZBAWIENIA" - WARUNKI POPRAWNEJ INTERPRETACJI \\ APOKALIPTYCZNEJ SYMBOLIKI Z LISTOWW DO TESALONICZAN}

\section{PRZEKŁAD TEKSTÓW}

A. Fragment archaicznego hymnu 1 Tes $1,9^{\mathrm{b}}-10$

,"9bZwróciliście się do Boga od〈-rzucając〉 bożków,

by służyć Bogu, żywemu i prawdziwemu

${ }^{10}$ i oczekiwać z niebios Jego Syna,

którego wskrzesił z martwych - Jezusa -

naszego Wybawcę od nadchodzącego gniewu."

B. Perykopa 1 Tes $4,13-18$

,${ }^{13} \mathrm{Nie}$ chcemy, bracia, żebyście trwali w niewiedzy co do 〈losu〉 śpiących 〈snem pokoju〉 - żebyście się martwili jak ludzie pozostali,

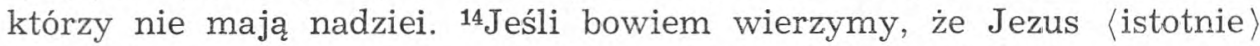
umarł i zmartwychwstał - 〈wierzymy również, że〉 tak samo i tych, którzy zasnęli dla Jezusa, Bóg wyprowadzi razem z Nim. ${ }^{15}$ To bowiem wam głosimy opierając się na słowie Pańskim 9: my żywi, 〈tutaj〉 pozostawieni do chwili paruzji ${ }^{10}$ Chrystusa, na pewno nie wyprzedzimy tych, którzy posnęli. ${ }^{16}$ Bo sam Pan zstąpi z ni eba, i - na $\langle\mathrm{J}$ e go $\rangle$ rozkaz, nagłos Archaniołaczylina 〈głos〉traby Bożjzmarli w Chrystusie powstaną pierwsi. ${ }^{17}$ Następnie my żywi, 〈tutaj〉 pozostawieni, razem i równocześnie z nimi zostaniemy porwani w o b ł o-

9 En lógō kyriou uważamy za celownik nadrzędny.

10 Wyraz parousia w 1-2 Tes jest terminem ściśle technicznym - oznacza powtórne przyjście Chrystusa w chwale i majestacie (w 2 Tes 2, 9 parodię tego przyjścia: objawienie się „Bezbożnika”), dzień powszechnego zmartwychwstania (1 Kor 15, 23), nagrody za czyny dobre i kary za czyny złe (1 Kor 3, 13-15; 4, 5; 2 Kor 5, 10), dzień, w którym nastąpi ,wyzwolenie całego stworzenia"' (Rz 8, 19-21), dzień, od którego począwszy ,zawsze będziemy z Panem" (1 Tes 4, 17). Bogactwo treści, jakie kryje w sobie ten termin, skłania nas do zaniechania prób jego przekładu na język polski. Przyjmujemy ten termin jako terminus technicus w teologii. Terminami uzupelniającymi treść pojęcia parousia są epipháneia i apokálypsis (u Pawla: 2 Tes 1, 7; 1 Kor 1, 7; Rz 2, 5; 8, 19; 16, 25). Termin epipháneia pojawia się we wczesnych pismach Pawła tylko raz (w 2 Tes 2, 8) i to w zestawieniu $\mathrm{z}$ terminem parousia. W Listach Pasterskich natomiast termin epipháneia wszedł całkowicie na miejsce terminu parousia. O ile autorem Listów Pasterskich jest Paweł - ta zmiana terminologii wskazuje na charakterystyczny zwrot w sposobie myślenia Apostoła. Najpierw myślał przede wszystkim o powrocie Chrystusa, który wstąpił do nieba (parousia), potem podkreślał prawdę o tym, że powtórne przyjście Pana będzie jedynie ,ukazaniem się" (epipháneia), ,objawieniem się" (apokálypsis) Pana Jezusa Chrystusa, który teraz cały czas jest obecny i działa wśród nas. Rzecz staje się jeszcze bardziej klarowną, jeśli 2 Tes 2, 8 nie jest zdaniem napisanym przez Pawła (zob. przyp. 8). W ten sposób teologia Pawła zbliża się do teologii Janowej. 
$\mathrm{kach}$ na spotkanie Pana - w przestworza. Tak więc na zawsze będziemy z Panem. ${ }^{18} \mathrm{~A}$ zatem pocieszajcie się nawzajem ppouczeniem zawartym $\rangle$ w tych słowach."

C. Perykopa 2 Tes $1,6-10$

,... ${ }^{6}$ Przecież jest rzeczą sprawiedliwą w oczach Bożych uciskającym was oddać ucisk, ‘a wam, uciśnionym - odpoczynek wraz z nami $\mathrm{w}\langle$ chwili〉 objawienia się Pana Jezusa. 〈Zstąpi On〉 z nie ba, z a ni ołami swej mocy, ${ }^{8} \mathrm{w}$ płonącym ogniu - i da sprawiedliwą zapłatę tym, którzy nie znają Boga, i tym, którzy nie są posłuszni ewangelii Pana naszego Jezusa. ${ }^{9}$ Jako sprawiedliwą karę poniosą oni wieczną ruinę, 〈odrzuceni〉 sprzed oblicza Pana i od potężnego majestatu Jego. ${ }^{10}\langle$ Stanie się to $\mathrm{w}$ owym dniu, gdy przyjdzie, aby zostać uwielbionym pośród świętych swoich i stać się przedmiotem podziwu wśród wszystkich, którzy uwierzyli (a wyście uwierzyli świadectwu naszemu!)”.

D. Perykopa 2 T es 2, 1-14

„Prosimy was, bracia, abyście w sprawie paruzji Pana naszego Jezusa Chrystusa i naszego zgromadzenia wokół Niego ${ }^{2 n i e}$ dali się zbyt łatwo zachwiać w waszym rozumieniu, ani też zastraszyć - czy to przez Ducha, czy to przez mowę, czy to przez list (od nas rzekomo pochodzący) - jakoby 〈już teraz〉 nastawał dzień Pański. ${ }^{3}$ Niech was w żaden sposób nikt nie zwodzi. Bo〈dzień ten nie nadejdzie〉 zanim nie przyjdzie najpierw odstępstwo i nie objawi się Człowiek Bezbożny, Zatraceniec, ${ }^{4}$ który się sprzeciwia i wynosi ponad wszystko, co nazywa się Bogiem, albo odbiera cześć - tak, że zasiądzie w świątyni Boga dowodząc, że to on właśnie jest Bogiem... ${ }^{5} \mathrm{Czy}$ nie pamiętacie, jak mówiłem wam o tym, kiedy wśród was przebywałem? ${ }^{6} \mathrm{~A}$ teraz $\langle z$ doświadczenia $\rangle$ znacie jego uwodzicielską moc - objawiła się bowiem w swoim czasie! ${ }^{7} \mathrm{Już}$ bowiem teraz działa misterium bezbożności... Niech tylko ten, co teraz zwodzi, zostanie usunięty ${ }^{11},{ }^{\mathrm{a}}$ a wtedy ukaże się Bezbożnik, którego Pan Jezus zmiecie precz $\mathrm{t} \mathrm{ch}$ hie $\mathrm{niem}$ ust $\mathrm{sw}$ o i ch - unieszkodliwi 〈samym〉 objawieniem swojej paruzji. ${ }^{9}$ Przyjściu tego 〈Bezbożnika〉 towarzyszyć będzie działanie szatana - z całą mocą, wśród znaków i fałszywych cudów, ${ }^{10} \mathrm{z}$ wszelkim zwodzeniem ku nieprawości tych, którzy giną, ponieważ nie przyjęli miłości prawdy, aby dostąpić zbawienia. ${ }^{11 D l a t e g o}$ Bóg dopuszcza, by działał na nich błąd tak, iż uwierzą kłamstwu ${ }^{12}$ by byli osądzeni wszyscy, którzy zamiast uwierzyć prawdzie, upodobali sobie nieprawość... ${ }^{13}$ Lecz my zawsze winniśmy dziękować Bogu za was,

11 Przekład wierszy 6-7 na podstawie pracy: Ch. H. Giblin, The Threat to Faith - an Exegetical and Theological Re-examination of 2 Tesalonians 2, Rome 1967. Znaczenie kontrowersyjnego ho katéchön - „ten, który włada”, „ten, który zwodzi” (a nie: ,ten, który powstrzymuje”) - zob. s. 204-242 oraz 244-248. 
umiłowani przez Boga bracia, bo wybrał was Bóg do zbawienia jako pierwociny - przez uświęcenie Ducha i wiarę w prawdę - ${ }^{14}$ wezwał was przez nasze głoszenie ewangelii do tego, abyście otrzymali na własność chwałę Pana naszego Jezusa Chrystusa".

\section{PARUZJA JAKO „DZIEŃ GNIEWU” I „DZIEÑ ZBAWIENIA”}

Już pierwszy spośród przedstawionych tekstów (1 Tes $\left.1,9^{\mathrm{b}}-10\right)$ sugeruje, że zbliżająca się paruzja Chrystusa, Jego objawienie się, będzie dla tych, którzy „zwrócili się do Boga odrzucając bożków, by służyć Bogu żywemu i prawdziwemu" dniem wybawienia od nadchodzącego gniewu orgè.

Ten schemat orgē-sōtēría ${ }^{12}$ zachowany jest we wszystkich trzech pozostałych tekstach, chociaż treść odpowiadająca tym określeniom bywa ujęta w różnych proporcjach. Ogólnie mówiąc akcent spoczywa na prawdzie o mocy Chrystusa-Kyriosa, który zbawi tych, którzy są Jego: zasadniczym „klimatem” dnia parupzji jest sōtēría. Wylanie się gniewu Bożego (orgē), usunięcie koszmaru zła, ukazuje się $\mathrm{w}$ tej perspektywie $\mathrm{z}$ jednej strony jako manifestacja mocy Chrystusa, z drugiej zaś - jako warunek, bez spełnienia którego pełne zbawienie nie mogłoby być urzeczywistnione.

A. Dzień gniew u

"Ów dzień" (2 Tes 1, 10) paruzji Pana będzie ,dniem gniewu” (Rz 2, 15 por. 1 Tes 1, 10), dniem sądu (2 Tes 1, 4; 2, 12) nad Szatanem i Bezbożnikiem (2 Tes 2, 8n), nad Człowiekiem Bezbożnym, który się sprzeciwia i wynosi ponad wszystko, co nazywa się Bogiem, albo odbiera cześć (2 Tes 2, 3n), nad tymi, którzy nie znają Boga (2 Tes 1, 8) - którzy grzeszą przez to, że nie rozpoznają Boga w tym świecie. Będzie to dzień gniewu i sądu nad tymi, którzy nie są posłuszni ewangelii Pana naszego Jezusa Chrystusa (2 Tes 1, 8) - nie uznali, że Jezus Chrystus jest Panem (Flp 2, 11), mimo że ewangelia do nich dotarła; nad tymi, którzy nie przyjęli miłości prawdy, aby dostąpić zbawienia (2 Tes 2, 10), którzy zamiast uwierzyć prawdzie - upodobali sobie nieprawość i uwierzyli kłamstwu (2 Tes 2, 12), którzy obecnie prześladują i uciskają tych, co się nawrócili (2 Tes 1, 4-6), którzy dopełniają miary swoich grzechów (1 Tes 2, 16).

Ci wszyscy otrzymają sprawiedliwą karę, zapłatę - za ucisk dostaną ucisk (2 Tes 1, 6): zostaną odrzuceni sprzed oblicza Pana (2 Tes 1, 9) nie będą z Panem (1 Tes 4, 17) - czyli nie będą mieli czegokolwiek, co ma jakąś wartość ${ }^{13}$. Zostaną odrzuceni od potężnego majestatu Jego (2 Tes 1,9) - nie zostaną uwielbieni. Zostaną na zawsze pozbawieni dóbr

12 Zob. 1 Tes 1, 10; 2 Tes 2, 10. 13. Zestawienie obu terminów: 1 Tes 5, 9.

13 B. Rigaux, Les Epîtres aux Théssaloniciens, kom. cyt., 632. 
Królestwa Bożego (zob. Mk 10, 37 i $M t$ 4, 21). Bezbożnik - indywiduum czy zespół ludzi złączonych z Szatanem - zostanie unieszkodliwiony samym objawieniem się paruzji Pana (2 Tes 2, 8) - poniesie wieczną ruinę $(2$ Tes 1,9$)$. Stan kary w jakim wszyscy wymienieni się znajdą nie będzie zatraceniem w sensie annihilacji, będzie jednak zaprzeczeniem życia wiecznego $(R z 2,7 ; 5,21 ; 6,22 ; G a 6,8)$ - będzie to wiecznie trwający grzech (Mt 3, 29), wieczny ogien (Mt 18, 8; 25, 41; Jud 7), wieczne potępienie (Mt 25, 46).

W ten sposób skończy się raz na zawsze działanie Misterium Bezbożności (2 Tes 2, 7).

\section{B. Dzień zbawienia}

Ów dzień paruzji Pana będzie dla tych, którzy żyją i umierają w Chrystusie i dla Chrystusa dniem wybawienia od gniewu (1 Tes 1, 10), dniem, w którym nastąpi ostateczne ich zbawienie - sōtēría (2 Tes 2, 10, 13). Wybawieni od gniewu i zbawieni będą ci ludzie, którzy postępowali tutaj, za życia, w sposób diametralnie różny od ludzi opisanych wyżej: przyjęli słowo Apostoła jako słowo Boże (1 Tes 1, 9), odwrócili się od bożków (1,9), uwierzyli prawdzie (2 Tes 1, 10;2, 13), ewangelii $(2,14)$; stoją przy Panu (1 Tes 3,8$)$, są naśladowcami Pana Jezusa i Pawła $(1,6)$, są synami światłości i synami dnia $(5,5)$, zmarli w Chrystusie (4, 14), są Jego świętymi (2 Tes 1, 10), są dla Apostoła nadzieją, radością, wieńcem chwały przed Panem $\mathrm{w}$ chwili Jego paruzji (1 Tes 2, 19).

Zbawienie tych wszystkich - rozpatrywane od strony negatywnej będzie polegało na tym, że Jezus, chwalebny Syn Boży, wybawi ich od nadchodzącego gniewu $(1,10)$ - dostąpią odpoczynku od wszystkich prześladowań i ucisków (2 Tes 1,7 por. $M t$ 11, 29).

Zbawienie ich rozpatrywane od strony pozytywnej obejmuje wydarzenia następujące: ci, którzy zasnęli dla Jezusa (1 Tes 4, 14), którzy zmarli w Chrystusie - powstaną z martwych (4, 14. 16). Wraz z tymi, których paruzja zastanie przy życiu spotkają się z Panem $(4,17)$, zostaną zgromadzeni wokół Pana (2 Tes 2, 1). Dostąpią odpoczynku - nadejścia upragnionej ochłody $(2,1 ; D z 3,20)$. Wśród nich i w nich zostanie Pan uwielbiony (2 Tes 1,10$)$, stanie się dla nich przedmiotem podziwu (2 Tes $1,10)$ - ich nadzieja, nadzieja chwały $(R z 5,2)$, zostanie w pełni urzeczywistniona: otrzymają na własność chwałę (doxa), Pana naszego Jezusa Chrystusa (2 Tes 2, 14; por. 1 Tes 5, 9). Cel naszego istnienia będzie nieodwracalnie osiągnięty - zawsze będziemy z Panem (1 Tes 4, 17).

Ta właśnie nauka o paruzji Chrystusa jako o „dniu gniewu” i „dniu zbawienia" przyozdobiona jest apokaliptyczną symboliczną szatą literacką, 
którą stanowią określenia: rozkaz, głos Archanioła, głos trąby Bożej, niebo, aniołowie mocy Pana, płomień ognia, obłoki, przestworza, tchnienie ust Pana. Pragniemy teraz przedstawić warunki poprawnej ich interpretacji.

\section{WARUNKI POPRAWNEJ INTERPRETACJI APOKALIPTYCZNEJ SYMBOLIKI Z LISTÓW DO TESALONICZAN}

Dla egzegezy eschatologia jest polem pracy szczególnie trudnym. Według określenia R. Schnackenburga jest ona ,rozpalonym żelazem, które nie bardzo wiadomo jak chwycić" ${ }^{14}$. Uwaga ta odnosi się chyba przede wszystkim do zadania trafnego wyjaśnienia poszczególnych elementów szaty literackiej opisów wydarzeń eschatologicznych - a więc do podejmowanego przez nas zadania teologicznej interpretacji symbolicznych określeń szkicujących obraz paruzji Chrystusa w 1-2 Tes. Jeśli próba uchwycenia treści teologicznej tych określeń - próba uchwycenia tego „rozpalonego żelaza” - ma przynieść wyniki pozytywne, konieczną jest rzeczą zaopatrzenie się w odpowiednie narzędzia pracy. Są nimi w tym wypadku zasady hermeneutyczne. Spróbujmy je sprecyzować.

Oba Listy do Tesaloniczan, mimo że mają walor ponadczasowy jako pisma natchnione przez Ducha Swiętego, pisane jednak były do ludzi z konkretnego środowiska - do określonej wspólnoty chrześcijańskiej drugiej połowy I wieku. Chcąc zatem poprawnie zrozumieć treść zawartych w tych Listach tekstów eschatologicznych, należy wczuć się w psychikę ich pierwotnych odbiorców, starać się odczytywać te teksty tak, jak odczytywali je oni. Inaczej mówiąc: należy zbadać, jakie były „,masy apercepcyjne" tych, do których kierował swoje Listy Apostoł Narodów.

Dotarcie do tego podłoża, do gleby, na którą padało słowo Apostoła, jest jednakowoż możliwe. Możliwym czyni je sam tekst Listów. Widać w nim bowiem wyraźnie, jak jego Autor z jednej strony ciągle odwoluje się do przekazanego już Tesaloniczanom zasadniczego zrębu nauki ewangelicznej, z drugiej zaś - jak bardzo często nawiązuje do tradycji starotestamentalnej.

Fakty te skłaniają do sformułowania następującego wniosku: badanie, jakie znaczenie mają symbole apokaliptyczne z $1-2$ Tes $\mathrm{w}$ pismach $S T$, a niekiedy $\mathrm{w}$ interpretacjach tekstów biblijnych podawanych przez pozakanoniczną literaturę judaistyczną, oraz badanie ich znaczenia w pismach NT - będzie wejściem w ,klimat intelektualny”, w którym żyli pierwsi chrześcijanie z Tesaloniki, będzie odkrywaniem skojarzeń, jakie indukowały w ich umysłach słowa Apostoła. Inaczej mówiąc - badanie to doprowadzi wprost do właściwego odczytania przekazywanych w Listach myśli.

14 Neutestamentliche Theologie, dz. cyt., 140. 
Twierdzenie to może jednak budzić pewne wątpliwości. Wydawać się może, że przypisywanie mieszkańcom greckiego miasta Tesaloniki formacji intelektualnej analogicznej do formacji intelektualnej chrześcijan palestyńskich - chrześcijan pochodzenia żydowskiego - jest zupełnym nieporozumieniem. Kto chce odczytać teksty Listów do Tesaloniczan tak, jak odczytywali je Tesaloniczanie - mówi wielu egzegetów ${ }^{15}$ - musi się oprzeć na współczesnej odbiorcom Listów literaturze i kulturze greckiej: wejść w świat myśli greckiej połowy I wieku.

$\mathrm{Na}$ pierwszy rzut oka wydaje się, że takie właśnie postawienie sprawy jest całkowicie i jedynie słuszne. Bliższe jednak przebadanie interesujących nas tekstów z $1-2$ Tes, a szczególnie przebadanie kwestii pochodzenia tak podstawowych dla eschatologii terminów jak parousía, apántēsis i epipháneia dokonane przez J. Dupont'a ${ }^{16}$ skłania nas do daleko posuniętej nieufności względem sugerowanej metody. Opisy „,paruzji” czy „epifanii” władców helleńskich, na których spotkanie - eis apántèsin - wychodzili obywatele miasta 17 nie mogą być całkowicie pominięte podczas interpretacji tekstów eschatologicznych ${ }^{18}$, należy jednak pamiętać, że jeśli do nich nawiązuje Apostoł, to nie w sposób bezpośredni. Opisy tych helleńskich „,paruzji” i „epifanii” zostały już dużo wcześniej wyzyskane przez autorów greckich przekładów ST. Przyswoili oni sobie greckie terminy parousía, apántēsis i epipháneia i napełnili je zupełnie nową treścią. Dziedzictwo to przejęli członkowie pierwszych wspólnot chrześcijańskich ${ }^{19}$, a w ich liczbie i Paweł.

Należy ponadto zauważyć, że teksty eschatologiczne Listów do Tesaloniczan - z całą ich szatą literacką - są niezwykle zbliżone do tekstów eschatologicznych innych ksiąg $N T^{20}$, szczególnie zaś do tekstów „apokalipsy synoptycznej” 21. Podobieństwo to tłumaczy zresztą stwierdzenie Pawła zawarte w 1 Tes 4, 15: Apostoł zupełnie wyraźnie mówi, że w głoszonej przez siebie nauce o przyszłym losie umarłych w Chrystusie opiera się na ,słowie Pańskim”.

15 J. Dupont, Sýn Christō - l'union avec le Christ suivant saint Paul, Bruges-Louvain-Paris 1952, 48 - wymienia $\mathrm{m}$. in. nazwiska następujące: A. Deissman, P. Wendland, K. Deissner, F. Prat, B. Rigaux, F. Amiot, L. Cerfaux, P. Benoit.

16 Tamże, 49-79.

17 Zob. B. Rigaux, Les Êpîtres aux Tess., kom. cyt., 230 n.

18 Odwoływał się do nich podczas wyjaśniania tekstów z 1-2 Tes już św. Jan Chryzostom (In 1 Tes. Hom. VIII, $1-P G 50,450$ n., por. PG 62, 440).

${ }_{19}$ Zob. np. grecki przekład słów Jezusa w $M t$ 25, 6: „Oto oblubieniec nadchodzi, wyjdźcie mu na spotkanie - eis apántē sin".

$202 P 3,10 ; 1$ Kor 15, 23n. 51n oraz liczne teksty Apokalipsy Janowej.

21 „Ukaże się na niebie znak Syna Człowieczego - i wtedy narzekać będą wszystkie narody ziemi. I ujrzą Syna Człowieczego przychodzącego na obłokach niebieskich z wielką mocą i chwałą. Pośle On swoich anio-

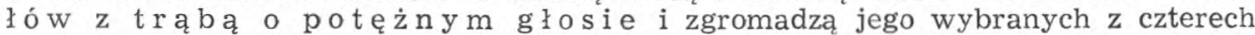
stron świata - od jednego krańca nieba aż do drugiego" ( $M t$ 24, 30n. Por. $M k$ 13; $\succeq k 21$ oraz $M k 14,62$ i par.). 
Uciekanie się przy interpretacji ,słów Pańskich" do kręgu wyobrażeń świata greckiego byłoby na pewno postępowaniem błędnym, skoro słuchacze Jezusa byli członkami narodu, który się od tego świata świadomie odcinał. Droga do poprawnego odczytania symboliki ,apokalipsy synoptycznej" prowadzi bez wątpienia przez nakładające się warstwy tradycji starotestamentalnej. Wniosek narzuca się sam: zbieżność interesujących nas tekstów z 1-2 Tes z tekstami „apokalipsy synoptycznej” wskazuje na konieczność odbycia podczas ich interpretacji drogi takiej samej, jaką należy odbyć podczas interpretacji tekstów ,,apokalipsy synoptycznej" — ,słów Pańskich".

Ostatni argument przemawiający za koniecznością oparcia się na tradycji biblijnej w naszym odczytywaniu symboliki tekstów apokaliptycznych z 1-2 Tes jest następujący: gdy zwrócimy uwagę na rzeczywisty skład osobowy młodej wspólnoty chrześcijańskiej w Tesalonice zauważamy, że trzonem jej nie byli Grecy, nieobeznani zupełnie z tradycją biblijną. Przeciwnie: obok chrześcijan wywodzących się z Izraelitów diaspory trzon wspólnoty stanowili "Grecy-pobożni” (hoi sebómenoi) - sympatycy judaizmu ${ }^{22}$ - którzy wraz z Izraelitami w każdy szabat zbierali się w miejscowej synagodze na wspólne czytanie i wyjaśnianie Pisma oraz na wspólną modlitwę (por. Dz 17, 1-9). Gleba więc pod zasiew ewangeliczny była już przygotowana.

A zatem podstawowy warunek poprawnej interpretacji apokaliptycznej symboliki z Listów do Tesaloniczan brzmi: nale ży z d e c y dowanie oprzeć się na tradycji biblijnej.

Inne więc uwagi $\mathrm{z}$ zakresu hermeneutyki ${ }^{23}$ będą następujące:

1. Semickich określeń symbolicznych - mimo że niekiedy wydają się wskazywać na rzeczywistości bardzo konkretne, materialne - nigdy nie wolno brać dosłownie. Celem bowiem autora, który się nimi posługiwał było naprowadzenie odbiorców jego pism na prawdy o charakterze duchowym.

2. Symbole semickie nie są tak przejrzyste jak symbole Greków. Mają dużą giętkość znaczeniową i wielozna c zność. Kilka różnych symbolów może wskazywać na rzeczywistość tę samą, i przeciwnie - jeden symbol może zmieniać swoje

22 Zob. K. Romaniuk, Il timore di Dio nella teologia di San Paolo, Brescia 1967, 109-124.

${ }_{23}$ Por. H. U. von Balthasar, Eschatologie, w: Fragen der Theologie heute (dz. zbiorowe), Einsiedeln-Zürich-Köln 1957, 403-423; A. Jankowski, Postulaty hermeneutyczne rodzaju literackiego Apokalipsy, w: Apokalipsa świętego Jana, Poznań 1959, 79-83 i 99-101; K. Rahner, Eschatologie, w: Lexikon für Theologie und Kirche ${ }^{2}$ (cyt. dalej: LThK ${ }^{2}$ ) 3 (1959) 1094-1098; tenże, Theologische Prinzipien der Hermeneutik eschatologischer Aussagen, "Zeitschrift für katholische Theologie" (cyt. dalej: ZKTh) 82 (1960) 137-158. 
znaczenie zależnie od kontekstu, w jakim został użyty; może też mieć kilka znaczeń równocześnie.

3. Przy interpretacji symboli z $1-2$ Tes, mimo że pochodzą z tradycji starotestamentalnej, należy uwzględnić ich transpozycję chrześcijańską.

4. Należy zgodzić się ze ,znamiennym dla apokaliptyki prawem 'światłocienia' " zgodzić się z faktem, że „nie wszystko da się w niej wyjaśnić more geometrico. Swiałocień zachodził zresztą i w proroctwach mesjańskich. Dopiero ich realizacja usunęła mroki obrazu" ${ }^{24}$. N a le ży pamiętać, że stale obracamy się w kręgu misteri i m ${ }^{25}$.

Dodatkową uwagę $\mathrm{z}$ zakresu hermeneutyki przynosi dokonana już refleksja nad treścią doktrynalną interesujących nas perykop. Mianowicie: symbole apokaliptyczne należy rozpatrywać w kontekście „dnia gniewu” i ,dnia zbawienia”.

24 A. Jankowski, tamże, 100.

25 Apostołowie są „szafarzami tajemnic, misteriów Bożych" (1 Kor 4, 1). Toteż określenie mystêrion pojawia się bardzo często jako - konieczny widać według Pawła - element uzupełniający ważnego dla nas określenia: apokálypsis (Rz 16, 25; Ef 3, 3), apokalýptein (1 Kor 2, 10; Ef 3, 5) i phaneroûn (Rz 16, 26; Kol 1, 26; 4, 4). 
Część druga

\section{INTERPRETACJA SYMBOLI}

I. ZMARLI W CHRYSTUSIE POWSTANA Z MARTWYCH ,NA ROZKAZ (PANA): NA GEOS ARCHANIOEA, CZYLI (NA GEOS) TRĄBY BOŻEJ” (1 Tes 4, 16)

\section{A. $\mathrm{Rozkaz}$}

W Nowym Testamencie określenie tô kéleusma (w formie rzeczownikowej) nie występuje. W $S T$ ( $L X X)$ jedynie w Prz 30, 27, gdzie ma znaczenie ,rozkaz”. W literaturze pozabiblijnej oznacza: rozkaz, głos wydający rozkaz, sygnał przekazujący rozkaz ${ }^{26}$.

Powstaje pytanie, kto i komu wydaje w 1 Tes 4, 16 rozkaz, oraz czego ten rozkaz dotyczy. Pewnej odpowiedzi na to pytanie nie ma ${ }^{27}$. Wydaje się jednak, że najbardziej prawdopodobna odpowiedź brzmi, jak następuje: skoro: kéleusma pojawia się po tytule Chrystusa Kýrios — po tytule wskazującym na Jego suwerenną władzę i majestat — należy uważać, że rozkaz jest wydawany przez tego właśnie Kyriosa-Pana, skierowany jest do ludzi, dotyczy ich zmartwychwstania.

Wydaje się ponadto, że pozbawione dopełniacza kéleusma wyjaśniane jest i uzupeiniane przez dwa następujące po tym rzeczowniku określenia, połączone ze sobą przez jedyne w interesującym nas zwrocie kai 28 . A zatem uwagę należy zwrócić przede wszystkim na te dwa określenia uzupełniające.

\section{B. Głos Archanioła}

Określenie archángelos w NT występuje jedynie w Jud 9 w zestawieniu ho Michaèl ho archángelos. List Judy nawiązuje tu do przekazów apokaliptyki judaizmu, dotyczących walki Michała archanioła z Szatanem o ciało Mojżesza ${ }^{29}$. Jednak w 1 Tes 4, 16 termin archángelos wystę-

26 W. Bauer, Griechisch-deutsches Wörterbuch..., Berlin ${ }^{5}$, s. v.; por. L. Schmid, Theologisches Wörterbuch zum NT (cyt. dalej: ThWNT) 3, 656n.

27 L. Schmid, tamże.

${ }_{28}$ Spójnik ten nie jest $\mathrm{w}$ grece biblijnej ścisłym odpowiednikiem polskiego spójnika „i” - ma znaczeń wiele. Jednym z nich jest wyjaśniające „czyli”. Dwa określenia połączone przez takie kaí tworzą zwrot zwany hendiadys (zob. W. Bauer dz. cyt., 776, 3; F. Blass, A. Debrunner, Grammatik des nt. Griechens, Göttingen ${ }^{8}$ 1949, § 442, 16; M. Zerwick, Graecitas biblica exemplis illustratur, Romae ${ }^{4} 1960$, $\S 460)$. Przykładem takiego użycia spójnika kaí jest w grece $N T \mathrm{np}$. zdanie Pawła z $D z$ 23, 6, wypowiedziane przed Sanhedrynem: perî elpídos kaí anastáseōs nekrōn egō krínomai - „Jestem sądzony ze względu na nadzieję, c z y li [ze względu na naukę o] zmartwychwstaniu ciał". Podobne użycie spójnika kaí znajdujemy np. u $M t$ 11, 24 lub $A p$ 14, 17. Wydaje się, że właśnie w takim sensie użyty jest on w 1 Tes 4,16. Treść trzeciego członu zwrotu en keleúsmati - en phonē archangélou kaí en sálpingi theô̂ stanowi powtórzenie i uzupełnienie drugiego.

29 H. L. Strack, P. Billerbeck, Kommentar zum NT aus Talmud und Midrasch, (cyt. dalej: Billerbeck) München²1956, 3, 786n. 
puje w całkiem innym kontekście, poza tym rzeczownik ten pozbawiony jest rodzajnika. Jedno i drugie identyfikacji z Archaniołem Michałem nie sprzyja.

W $S T$ termin ten nie występuje. Istnieje jednak pewien jego odpowiednik w $D n$ 12, 1 - a mianowicie określenie ho ángelos ho mégas, „wielki anioł" "30. Odnosi się ono do archaniołów Michała i Gabriela.

Użycie tego terminu w znaczeniu zupełnie innym pojawia się dopiero w pismach Filona: Termin archángelos występuje w nich zamiennie $\mathrm{z}$ terminem lógos ${ }^{31}$. Fak ten jest o tyle ważny, że pisma Filona mogły być właśnie nową lekturą Tesaloniczan, i do niej mógł nawiązywać ich Apostoł ${ }^{32}$.

Zwróćmy teraz uwagę na sam "głos" - phōnē. Jak już powiedziano cały interesujący nas zwrot mówi najprawdopodobniej o rozkazie skierowanym przez Chrystusa do tych, ,którzy zasnęli, umarli”. Otóż głos Chrystusa pojawia się w analogicznym kontekście w $J 5,21$, a zwłaszcza w 5, 28: „Nadchodzi godzina, w której wszyscy, co spoczywają w grobach, usłyszą głos Syna Człowieczego (phōnē), i ci, którzy pełnili dobre czyny pójdą na zmartwychwstanie życia, ci zaś, którzy pełnili złe czyny na zmartwychwstanie potępienia".

\section{Głos trąby Bożej}

1. Przekład rzeczownika sálpinx

W LXX sálpinx - jako odpowiednik sześciu różnych terminów hebrajskich, z których występującym najczęściej jest šôfar — należy przekładać: „róg” ${ }^{33}$, „,dźwięk rogu”, ,sygnał”, ,alarm”. Jako odpowiednik hebrajskiego hass(e)rôt - trąba: instrument muzyczny $\mathrm{w}$ sensie właściwym, używany podczas liturgii świątynnej przez lewitów. Wymieniają go jedynie księgi: $L b, 2 \mathrm{Krl}, \mathrm{Ezd}, \mathrm{Ne}$.

A zatem w tekstach $S T$ mówiących o teofaniach i w tekstach eschatologicznych rzeczownik sálpinx należy przekładać „,róg”, „dźwięk rogu”. Nie chodzi w tych tekstach o żadną muzykę, o melodie wygrywane na trąbce, lecz o potężny głos, który Izraelici kojarzyli z głosem rogu, podobnym do głosu naszego puzonu. Wydaje się, że tak samo należałoby przekładać ten termin $\mathrm{w}$ tekstach eschatologicznych NT. Ponieważ jed-

30 Przekład hebrajskiego sar haggādôl lub sārîm (plur. maiestatis).

31 Omówienie tych tekstów: G. Kittel, ThWNT 1, 86; J. Barbel, Christos Angelos - die frühchristliche und patristische Engelchristologie im Lichte der neueren Forschungen, w: „Liturgie und Mönchtum, Laacher Hefte”, 21 (1957) 71-96.

32 Teoretycznie rzecz jest możliwa, gdyż Filon żyje w latach 20 przed n. e. 50 n. e. - W r. 50 - roku powstania 1 Tes - pisma jego mogły już dotrzeć do portowego miasta, jakim była Tesalonika, i wzbudzić zainteresowanie tamtejszych żydów i chrześcijan. Nie ma na to jednak żadnego dowodu pozytywnego.

33 Prymitywny instrument wykonany $\mathrm{z}$ rogu zwierzęcego, używany $\mathrm{w}$ czasie uroczystości narodowych i podezas bitew. 
nak określenie ,głos rogu" brzmiałoby w tych tekstach zbyt archaicznie - pozostawiamy w przekładzie tradycyjne określenie "głos trąby".

2. Opisy teofanii Starego Testamentu

„Głos rogu" rozlega się po raz pierwszy podczas teofanii na górze Synaj:

„Trzeciego dnia rano rozległy się grzmoty nad górą i rozległ się głos potężnego rogu, tak że cały lud przebywający w obozie drżał ze strachu (...) Góra Synaj była cała spowita dymem, gdyż Jahwe zstąpił na nią w ogniu (...). Głos rogu się przeciągał i stawał się coraz donioślejszy" 34 . „Głos rogu” jest tu najprawdopodobniej metaforą nie dającego się inaczej opisać głosu Boga ${ }^{35}$, co wydaje się potwierdzać komentarz tego miejsca zawarty w Pwt 5, 22: „Te słowa wyrzekł Jahwe do waszego zgromadzenia na Górze - spośród ognia, obłoku i ciemności — donośnym głosem".

3. Teksty eschatologiczne Starego Testamentu

„Jak ,głos potężnego rogu" rozlegał się podczas teofanii na górze Synaj - tak też odezwie się w ,dniu Jahwe”, w „dniu ostatecznym": będzie on głosem Bożego sądu względem grzeszników (So 1, 16; $J l 2,1$ ). Będzie on również głosem obwieszczającym zbawienie - zgromadzi tych, co byli rozproszeni, zgromadzi ich na Swiętej Górze, w Jeruzalem (Iz 27, 13). Według $Z a$ 9, 14-17 „w róg zadmie sam Jahwe, Bóg wszechmogący (...) i poprowadzi swój lud niby trzodę (...) do kraju dobrego i uroczego".

4. Teksty eschatologiczne pozakanonicznego judaizmu

Judaizm pozakanoniczny z czasów przed Chrystusem powtarza wiadomości i interpretacje dotyczące faktów eschatologicznych zawarte w pismach $S T{ }^{36}$. Myśl nowa pojawia się dopiero na przełomie I i II w. Według rabina Aqiby głos rogu wskrzesi w dniu ostatecznym umarłych:

„Bóg weźmie do ręki potężny róg. Skoro w ten róg zadmie - głos jego rozlegnie się po krańce ziemi. Na pierwszy odgłos rogu zadrży cała ziemia. Na drugi odgłos rogu zgromadzą się prochy. Na trzeci odgłos rogu połączą się kości. Na czwarty odgłos rogu kości obrosną ciałem. Na piąty odgłos rogu ciała zostaną przyodziane skórą. Na szósty odgłos rogu zstąpią w ciała ich dusze i duchy. Na siódmy odgłos rogu ciała zostaną ożywione - staną na nogi ludzie przyodziani w szaty."

Oto co znaczą słowa ,w róg zadmie Jahwe, Bóg wszechmogący" (Za 9, 14)" ${ }^{37}$.

34 Wj 19, 16. 18. por. 20, 18;Am.3, 6. 8; Iz 18, 3.

35 Por. G. Friedrich, ThWNT 7, 79n.

36 Najczęściej parafrazują wspomniany tekst $Z a$ 9, 14-17. Zob. Gm Friedrich, ThWNT 7, 84.

37 Jest to przykład interpretacji $\mathrm{Za} 9,14$ na przelomie I i II wieku w środo- 
5. Opisy teofanii i wizji w Nowym Testamencie

List do Hebrajczyków w opisie teofanii synaickiej "głos trąby" wymienia jako jeden $\mathrm{z}$ elementów scenariusza tej teofanii - obok „płonącego ognia”, ,gęstniejących ciemności”, „burzy” i „mowy Boga” (12, 9).

Apokalipsa porównuje głos przemawiający do Wizjonera (hōs) do głosu trąby $(1,10 ; 4,1)$. Kim jest przemawiający — nie wyjaśnia. W każdym razie można stwierdzić, że w dalszym opowiadaniu Apokalipsy głosy przemawiających aniołów nigdy nie są porównywane do głosu trąby. Wydaje się ponadto, że w 1, 10 i 4, 1 ,głos" należy uważać za głos Boga (por. 16, 1. 17), lub Chrystusa (por. 1, 12).

6. Nowotestamentalne teksty eschatologiczne

W rozdziałach 8-11 Apokalipsy trąb jest siedem i dmie w nie kolejno siedmiu aniołów. $\mathrm{Na}$ głos pierwszych sześciu spadają na ziemię klęski. W opowiadaniu panuje atmosfera grozy, mimo że plagi w swej istocie są dziełem Bożego miłosierdzia: mają skłonić ludzi do nawrócenia się ku Bogu $(9,20)$, ludzi, którzy stale wybierają zamiast życia z Bogiem śmierć, zamiast przebaczenia - zatratę $(9,6)$. Głos jednak trąby siódmej zmienia całkowicie nastrój opowiadania. Zapowiedziane „trzecie Biada!” $(11,14)$ jakby nie nadchodzi - nie ukazuje się już żadna scena kaźni. Całe niebo napełnia się radością, szczęściem, triumfem: „Gdy siódmy anioł zatrąbił - pisze Jan - w niebie powstały donośne głosy mówiące: 'Nastało nad światem królowanie Pana naszego i Jego Chrystusa i będzie królował na wieki wieków" " $(11,15)$. Radość wyrażają też głosy „,dwudziestu czterech starców”: „Nadeszła pora na umarłych, aby zostali osądzeni, i aby dać zapłatę sługom Twoim, Boże — prorokom i świętym!" A zatem głos siódmej i ostatniej trąby jest głosem zwiastującym zbawienie. Oczywiście prawda o sądzie i karze pojawia się tutaj także, jednak jakby na drugim planie: głos tej trąby zwiastuje ,nadejście gniewu Bożego (...) - zniszczenie tych, którzy niszczą ziemię" $(11,18)$.

Według Mt 24, 31 Syn Człowieczy w dniu ostatecznym ,pośle z potężną trąbą aniołów - zgromadzą oni Jego wybranych z czterech stron świata".

Według 1 Kor 15, 22 na "głos trąby ostatecznej" zmartwychwstaną umarli. Kto będzie dął $\mathrm{w}$ trąbę - nie jest powiedziane, podobnie jak nie jest powiedziane w 1 Tes 4, 16 .

wiskach żydowskich. O wzajemnej zależności wypowiedzi Aquiby i 1 Tes 4, 16 nie może być chyba mowy. Por. ThWNT 7, 84. 


\section{W N I O S K I}

Zwrot „na rozkaz Pana - na głos Archanioła, czyli na głos trąby Bożej" stanowi jedną, nierozerwalną całość. Pierwszy element tego zwrotu uzupełniany jest przez drugi i trzeci.

"Głos Archanioła" jest najprawdopodobniej metaforą głosu samego Chrystusa, jakkolwiek nie wyklucza się możliwości posługi Michała Archanioła, czy aniołów w ogóle. Podobnie rzecz się ma z głosem ,trąby Bożej”. „Głos trąby”, ,głos rogu” jest w pismach ST najprawdopodobniej metaforą nie dającego się inaczej opisać głosu samego Boga - w NT jest najprawdopodobniej metaforą głosu samego Chrystusa. Podobnie jak głos Jahwe słychać było na Synaju - głos Chrystusa zagrzmi w dniu ostatecznym. Jednym będzie zwiastował zbawienie, innym - potępienie.

Kontekst określeń „na rozkaz - na głos Archanioła, czyli trąby Bożej” - podobnie jak kontekst określenia z 1 Kor 15, 52: „,na głos trąby ostatecznej" - z nieodpartą koniecznością kojarzy te określenia (które Paweł podaje „opierając się na słowie Pańskim”) z zapowiedzią samego Pana Jezusa, przekazywaną przez św. Jana $(5,28)$.

A zatem stwierdzenie, że zmarli w Chrystusie powstaną z martwych „,na rozkaz - na głos Archanioła, czyli na głos trąby Bożej” przynosi następujące wzbogacenie prawd teologicznych przekazywanych przez 1 Tes 4, 13-18:

a) Pan Jezus przyjdzie z tą samą mocą i chwałą, z jaką objawiał się Bóg na Synaju. Wskrzeszenie zmarłych nie będzie dla niego przedstawiało najmniejszej trudności.

b) Zmartwychwstaną nie tylko ci, którzy pełnili czyny dobre i zmarli w Chrystusie - o czym powiedziane jest w 1 Tes 4, 13-18 w sposób wyraźny - lecz również zmarwychwstaną i ci, którzy pełnili czyny złe, o czym teksty Listów do Tesaloniczan wydają się milczeć. Pierwsi pójdą na zmartwychwstanie życia, drudzy - na zmartwychwstanie potępienia.

c) Zmarłych wskrzesi głos samego Chrystusa.

\section{II. „PAN ZSTĄPI (OBJAWI SIĘ) Z NIEBA ${ }^{38}$, Z ANIOEAMI SWEJ MOCY, W PEONĄCYM OGNIU"' (2 Tes 1, 7 n)}

\section{A. $\mathrm{Ni}$ e bo \\ 1. Teksty Starego Testamentu}

Gdy teksty $S T$ mówią o niebie ( żenie, że niebo jest czymś sporządzonym ze stałego, mocnego materiału -

38 Wf 1 Tes 4, 16: „Pan zstapi z nieba”. Analogiczny zwrot z 2 Tes 1, 7, fakt zstępowania $z$ nieba nazywa „objawieniem się $z$ nieba". W archaicznej formule z 1 Tes 1, 9b-10 zwrot ten występuje w 1. mn.: chrześcijanie oczekują Syna Bożego „z niebios”. 
jest rozpięte jak namiot (Ps 103[104], 2; Za 12, 1), ma okna ( $M l$ 3, 10), filary (Job 26, 11). Termin więc šāmaîm jest często odpowiednikiem terminu rāqîa $a^{c}$ oznaczającego prymitywnie rozumiany „firmament”.

Dużo częściej jednak niebo jest synonimem mieszkania Boga. Wspomniany już Ps 103[104], 2 n daje taki opis majestatu Boga:

„On światłem okryty jest jak płaszczem,

jak namiot rozpostarł niebo.

Nad górnymi wodami wzniósł swoje komnaty.

Na chmurach jedzie jak na rydwanie, przechadza się na skrzydłach wichru."

Jahwe ,z nieba” spogląda na ludzi (Pwt 26, 15), z nieba zsyła swoje błogosławieństwo ( $R d z$ 49, 25; Pwt 33, 13; $1 \mathrm{Krl} \mathrm{8,35)} \mathrm{-} \mathrm{toteż} \mathrm{Izraelici}$ modlą się z rękoma wzniesionymi do nieba (Pw.t 32, 40; Wj 9, 29. 33).

To miejsce przebywania Boga jest - mimo pozorów - bliskie. Bóg cały czas, nieustannie zajmuje się światem (por. Ez $1,1 \mathrm{nn}$ ). Wizja więc nieba, w którym Bóg ukryty jest daleko, za chmurami, jest wytworem wyobraźni ludzi stojących niemal na marginesie wiary Izraela (Job 22, 13; Koh 5, 1).

\section{Teksty Nowego Testamentu}

Termin ouranós występując w zestawieniu ouranôs kaì gē (np. Mt 8, 18. 34) oznacza wszechświat. Czasem - podobnie jak w pismach rabinistycznych ${ }^{39}$ - zastępuje imię Boga: odpowiednikiem np. zwrotu „królestwo Boże” $(M k)$ jest zwrot „królestwo niebios” $(M t)$.

Często spotykany w ewangeliach zwrot "Ojciec, który jest w niebie” i jemu podobne, wyjaśniany jest przez takie określenia jak: „Ojciec, który widzi w skrytości” (Mt 6, 4. 6. 18) czy „Ojciec, który wie” (6, 8. 32). Termin więc ,niebo" służy tutaj do wyrażenia tego faktu, że Bóg Ojciec jest Bogiem, którego nie krępują żadne ograniczenia związane nieodłącznie z naszym, ludzkim sposobem bytowania. Wszystko wie, wszystko widzi, wszystko może - jest blisko każdego z nas. A zatem „niebo" nie jest tutaj żadnym miejscem czy przestrzenią. Wskazuje raczej tylko na inny, transcendentny wymiar egzystencji, na absolutną bliskość naszego Boga, który stale wychodzi nam naprzeciw ze swoją zbawczą inicjatywą ${ }^{40}$.

To, że symboliczne określenie „niebo” ma takie właśnie znaczenie w interesujących nas tekstach z $1-2$ Tes, wynika z ich zestawienia z Mk 14, 62; Dn 7, 13 i Ps 109(110), 1. Okazuje się, że zwrot „Pan przyjdzie z nieba" jest odpowiednikiem zwrotów: „przyjdzie wśród obłoków nie-

39 Zob. G. Kuhn, ThWNT 1, 570 oraz 3, 93.

40 „Der Himmel bedeutet hier nicht eine zuständliche Orts sondern eine dynamische Ausgangsbezeichnung" (H. Traub, ThWNT 5, 520). 
bieskich”, ,z prawicy Bożej”, ,z prawicy mocy Bożej”, co — posługując się tekstami Mt 5, 34; 23, 22; Ap 7, 49; Hbr 8, 1 - można określić także „przyjdzie od tronu Bożego". Wszystkie te określenia wyrażają tę prawdę, że chwalebny Syn Boży przyjdzie w dniu swojej paruzji z inicjatywy Ojca jako równy mu Kyrios-Pan, że przyjdzie ze strefy Bożego bytowania ${ }^{41}$.

Określenie „Pan zstąpi, objawi się z nieba” oznacza też przybliżenie się ku nam naszej właściwej ojczyzny:

„Nasza bowiem ojczyzna jest w niebie, skąd też jako Zbawcy oczekujemy Pana naszego Jezusa Chrystusa, który przekształci nasze ciało poniżone do swojego chwalebnego ciała. (Dokona tego) tą potęgą, jaką może On także wszystko co jest sobie podporządkować" $(F l p 3,20)$.

Jest rzeczą charakterystyczną, że ilekroć w NT mowa jest o zstępowaniu Chrystusa ,z nieba" - niezmiennie pojawia się taki właśnie kerygmat dotyczący naszego zmartwychwstania i przemienienia 42 .

\section{W N I O S K I}

Termin ,niebo" nie oznacza w 1-2 Tes żadnej przestrzeni materialnej, żadnego „miejsca”. Wskazuje na inny, transcendentny wymiar egzystencji Boga i na Jego absolutną bliskość względem każdego z nas.

W kontekście „dnia zbawienia” stwierdzenie: „Pan zstąpi z nieba” oznacza, że Jezus Chrystus w dniu swojej paruzji przyjdzie ze strefy Bożego bytowania, z inicjatywy Ojca, jako równy Mu Kýrios - Pan żywych i umarłych. Wprowadzi On zbawionych w tę strefę swojego bytowania, która ma być także naszą, ma być „naszą ojczyzną” — dostąpimy pełnego udziału we wszystkich dobrach przyszłego eonu.

W kontekście zaś „dnia gniewu" stwierdzenie "Pan zstąpi z nieba” oznacza, że Jezus Chrystus przychodzący jako pełen mocy Kýrios ukarze nie pokutujących grzeszników z łatwością tą samą, ,z jaką może on także wszystko, co jest, sobie podporządkować" (Flp 3, 20).

\section{B. Aniołowie mocy Pana}

\section{Teksty Starego Testamentu}

W ST określenie male âk - podobnie jak jego grecki odpowiednik ángelos - ma znaczeń kilka: posłannictwo, wiadomość, posłaniec, zwiastun, anioł ${ }^{43}$. Znaczenie ,aniol" ma ono wtedy, gdy pojawia się w kontekście, który na to wyraźnie wskazuje - gdy mowa jest o posyłającym Bogu. Często jest to po prostu zestawienie „Anioł Jahwe”.

\footnotetext{
41 Por. H. Traub, ThWNT 5, 522; W. Grundmann, ThWNT 2, 38.

42 Teksty $\mathrm{z} 1-2$ Tes, 1 Kor 15, 20. 47 itp.

43 G. von Rad, ThWNT 1, 75-79.
} 
W okresie patriarchów, Mojżesza i sędziów ukazanie się anioła jest formą objawienia się niewidzialnego Boga ${ }^{44}$ : niepodobna dojść do całkowitej pewności, czy w rozmowie „Anioła Jahwe” z Hagar, z Abrahamem, z Mojżeszem lub Gedeonem ${ }^{45}$ ukazuje się i mówi anioł, czy też sam Bóg. Ani ,teoria reprezentacji”, ani „teoria identyfikacji”, ani też ,teoria interpolacji" sprawy całkowicie nie wyjaśnia ${ }^{46}$. O ile $w$ tych tekstach „anioł Jahwe" jest istotą różną od Boga, to należy stwierdzić, że jest to istota stojąca bardzo blisko Niego. W niej objawia się Jego „chwała”. W tym pierwszym okresie anioł ukazuje się niekiedy $\mathrm{w}$ roli opiekuna zesłanego przez Boga, aby służył pojedynczym ludziom lub całemu narodowi $(R d z 24,7 ; 28,12 ; W j 32,34 ; L b 20,16)$.

Zdecydowanie w tej właśnie roli opiekunów - posiańców Bożych niosących ludziom zbawienie - występują aniołowie w czasach królewskich. Sługom Bożym - jak np. Eliaszowi (1 Krl 19, 5 nn; Ps 33[34], 8) anioł niesie wybawienie, wrogom zaś i przeniewiercom niesie karę ( $2 \mathrm{Krl}$ 19, 35; $1 \mathrm{Krm} 21,12$ ).

W trzecim okresie historii religijnej Izraela - w czasach proroków aniołowie występują najczęściej $\mathrm{w}$ fantastycznych opisach dydaktycznych i w opisach eschatologicznych. Występują tu nadal jako stróżowie całego narodu (Dn 8, 15 n; 9, 21 n) lub jednostek, jak np. Trzech Młodzieńców, Zuzanny czy Daniela (Dn 3, 49; 13, 55. 99; 14, 39). Przede wszystkim jednak ukazywani są jako niebiańscy liturgowie (Iz 6; Dn 7). Podczas objawień i wizji otrzymywanych przez ludzi, aniołowie tłumaczą oglądane sceny - to angeli interpretes $(Z a 1,8 ; 2,2 \mathrm{nn})$. W okresie tym aniołowie występują też w roli ludzkich orędowników przed tronem Boga (Za 1, 12; Job 33, 23-26).

\section{Teksty Nowego Testamentu}

Chociaż pisma NT mówią o aniołach tylko ubocznie, gdy mowa jest o dziele zbawienia dokonywanym przez Chrystusa, szereg jednak rozsianych $\mathrm{w}$ różnych miejscach stwierdzeń pozwala na uzmysłowienie sobie, czym aniołowie są. Apokalipsa porównuje aniołów do gwiazd $(3,1)$ i do lamp ognistych $(4,5$. por. 1,$4 ; 5,6)$. Zmieniają oni dowolnie swoje miejsca - latają w przestworzach $(14,6$. por. 4, 7; 8, 13). List do Hebrajczyków nazywa anioły „wichrami” (pneúmata) i ,płomieniami ognia” (pyrós phlóx).

Cechy świetlistości, ognistości, duchowości jeszcze dobitniej są wyrażane przez towarzyszące cz̨ęsto terminowi ángelos określenia uzupełnia-

44 Tenże, Theologie des Alten Testaments, Berlin 1969, 1, 298-300; H. Gross, H. Schier, Die Engel in der heiligen Schrift, Leipzig 1961, 20.

45 $R d z$ 16, 7 nn; 18, 1; Wj 3, 2 nn; Sdz 6, 12 nn.

46 Por. J. Touzard, L'Ange de Yahweh, w: Dictionnaire de la Bible, Supplement, 1, $242-255$. 
jące - dýnamis lub ischýs oraz dóxa ${ }^{47}$. „Moc-potęga” i „chwała-blask-majestat" - przymioty właściwe zasadniczo samemu Bogu i Kyriosowi - są również przymiotami tych, którzy ,zawsze oglądają Boże oblicze" (Mt 18, 10). Dlatego też według $£ k 9,26$ Chrystus ma przyjść „,w swojej chwale, w chwale Ojca i świętych aniołów. Dlatego gdy ,,anioł Pański” się pojawia - „Światłość Pańska" opromienia ludzi (Łk 2, 9). Dlatego w Hbr 9, 5 aniołowie nazywani są "cherubinami chwały", a w 2 P 2, 10 oraz w Jud 8 krótko - dóxai.

Aniołowie już teraz spełniają ważną rolę w dziele zbawienia świata: towarzyszą ludziom za życia (Mt 18, 10;4, 6), objawiają ludziom wolę Bożą ( $\mathrm{Dz}$ 7, 30-38. 53; Hbr 2, 2), wybawiają z niebezpiecznych sytuacji ( $D z 5,19 ; 12,7)$, zabierają dusze ,na łono Abrahama” ( $E k$ 16, 22), opiekują się ludzkim ciałem po śmierci ( $J u d$ 9). Troszczą się nie tylko o jednostki, lecz także o całe wspólnoty wiernych $(A p 1,20 \mathrm{nn}){ }^{48}$.

W życiu Jezusa szczególnie często mowa jest o aniołach w opisach wydarzeń związanych $\mathrm{z}$ Jego narodzeniem ${ }^{49}$ i zmartwychwstaniem ${ }^{50}$. Fodobnie trzeci wielki akt realizacji zbawczego planu Boga przez Chrystusa, akt ostateczny - paruzja, również dokonywany jest przy współudziale aniołów: przyjdą wraz z Panem (Mt 16, 27; Mk 8, 38; £k 9, 26; 2 T'es 1, 7) i będą Jego sługami w chwili sądu ostatecznego (Mt 13, $38 \mathrm{n}$; Łk 12, 8). „Kto przyzna się do Syna Człowieczego wobec ludzi - przyzna się i Syn Człowieczy do niego wobec aniołów Bożych" (Łk 12, 8. por. 12, 9 i $A p 3,5 ; 14,10)$. "Sprawiedliwych zgromadzą z czterech stron świata” (Mt 24, 31), ,zlych odłączą od sprawiedliwych i wrzucą ich w piec rozpalony" (Mt 13, 49).

\section{W N I O S K I}

W kontekście „dnia zbawienia” stwierdzenie „Pan objawi się z aniołami swej mocy" oznacza, że w dniu paruzji Chrystusa objawi się chwała i moc Boża, nastąpi rozstrzygające spotkanie ludzkości z Bogiem, nastąpi definitywne oddzielenie sprawiedliwych od złych i od wszelkich ataków Szatana. Nastąpi zgromadzenie wybranych wokół Pana - wejdą oni w kręgi niebiańskiej liturgii.

W kontekście „dnia gniewu" ukazanie się wraz z Panem ,aniołów Jego mocy" oznacza oddzielenie wszystkich czyniących nieprawość od sprawiedliwych - dzień wymierzenia nie pokutującym grzesznikom kary „ognistego pieca”, „,ognia piekielnego".

\footnotetext{
47 Np. $M k$ 13, 26 (por. Dn 7, 13); 2 Tes 1, 7; Ap 5, 2; 2 P 2, 11.

48 H. Schlier, dz. cyt., 51. Por. E.-B. Allo, Apocalypse, Paris 1933, 27 (opinia 3).

49 Zob. J. Kudasiewicz, Ewangelie dzieciństwa Jezusa, ClctnTh 40 (1970) $163-166$.

50 W życiu publicznym tylko po scenie kuszenia $(M t 4,11 ; M k 1,13)$ i podczas konania w ogrójcu ( $₫ k 22,43 \mathrm{n})$.
} 
Należy ponadto zauważyć, że istnieje niejednokrotnie całkiem bliski związek treściowy między pojęciem anioł (ángelos), a pojęciami: tchnienie (pneûma), płomień ognia (pyr phlogós), moc (dýnamis), potęga (ischýs) oraz majestat-jasność-chwała (dóxa).

\section{Płonący ogień}

Występujące szereg razy w ST i NT zestawienie terminów pyr i phlóx w jeden zwrot pyr phlogós lub zamiennie używany phlóx pyrós oznacza tyle samo co każdy z tych terminów z osobna. Zestawienie ich wzmaga jedynie stopień emfazy ${ }^{51}$.

\section{Teksty Starego Testamentu}

a) Zjawiska towarzyszące wielkim teofaniom

„Mojżesz zawiódł pewnego razu owce w głąb pustyni i przyszedł do góry Bożej Horeb. Wtedy ukazał mu się anioł Pański w płomieniu ognia en phlogî pyrós - ze środka krzaku. Mojżesz widział, że krzak płonął ogniem, a nie spłonął od niego (...) - było to zjawisko niezwykłe" $(3,1-3$. por. $D z 7,30)$.

„Płomień ognia” podczas wszystkich teofanii jest manifestacją ,,chwały Jahwe". Wyraźnie mówi o tym opis teofanii na Synaju: gdy chwała Jahwe spoczęła na Synaju - „wygląd chwały Jahwe w oczach Izraela był jak ogień pożerający na szczycie góry" ( $W j 24,16$ n). Przedłużeniem tej teofanii jest obecność Jahwe w wędrującym obozie Izraela, objawiająca się $\mathrm{w}$ słupie dymu i w słupie ognia $(W j 13,21 ; 14,14)$.

Tymi samymi określeniami posługuje się apokaliptyczny tekst Daniela: „Starowieczny zajął miejsce (...), a tron Jego jakby płomień ognia” (7, $9 \mathrm{n})$.

b) Żywioł porywający do Boga to, w czym Bóg ma upodobanie

Gdy Gedeon złożył ofiary na skale, „wydobył się ogień ze skały i spalił mięso oraz przaśne chleby" ( $S d z 6,21)^{52}$.

Oprócz ognia będącego znakiem przyjęcia przez Boga ofiary, spotykamy także ogień porywający do nieba proroka. W $2 \mathrm{Krl} 2,11$ czytamy: zjawił się „,wóz ognisty z ognistymi rumakami (...) i Eliasz wśród wichru wstąpił do nieba".

c) Narzędzie Bożego gniewu

Pierwszym przykładem srożenia się gniewu Bożego nad grzesznikami jest ukaranie „deszczem siarki i ognia" mieszkańców Sodomy i Gomory $(R d z 19,24) . \mathrm{Na}$ dalszych kartach historii biblijnej czytamy, że ogień spadający z nieba ukarał zatwardziałych Egipcjan (Wj 9, 23; por. $A p$

51 W. Michaelis, ThWNT 6, 934-936, 941-947.

52 Podobne przykłady: $R d z 15,17 ; K p t 9,23 \mathrm{n} ; 1 \mathrm{Krl} 18,38$. 
8, 7), następnie nieposłusznych synów Aarona ( $K p t$ 10, 2), wysłańców króla Ochozjasza, którzy mieli pojmać Eliasza (2 Krl 1, 1, 10). Ukazuje się on również jako narzędzie gniewu Bożego w mowach proroków: ma on ukarać wrogów Izraela $(A m, 1,4 \mathrm{nn} J r 43,12)$, ukarze też samych Izraelitów, jeśli będą nieposłuszni ( $A m$ 2, 5; Jr 11, 16; Ez 16, 41). Karzący ogień Pana pojawia się też nieustannie w poematach apokaliptycznych. W Księdze Izajasza np. czytamy:

„Gniew Pana da się poznać Jego nieprzyjaciołom.

Bo oto Pan przybywa w ogniu,

a Jego rydwany pędzą jak burza -

by zaspokoić swój gniew pożogą

i groźby swoje płomieniami ognia.

Sądu dokonuje On przez ogień" ${ }^{53}$.

Po niewoli babilońskiej idea karzącego ognia wzbogaca się nieznaną dotąd prawdą o tym, że ogień ten jest nieugaszony, nie do ugaszenia. O karanych grzesznikach mówi Deutero-Izajasz, że „,robak ich nie zginie i nie zagaśnie ich ogień" 54 .

d) Ogień, który pali — ogień, który opromienia

Teksty eschatologiczne proroków ukazują niejednokrotnie ogień Bożego gniewu względem zatwardziałych grzeszników jako tę samą rzeczywistość, która uszczęśliwi zbawionych. W proroctwie Malachiasza np. czytamy:

„Zobaczycie różnicę między sprawiedliwym a krzywdzicielem, między posłusznym Bogu a tym, co Mu nie służy. Bo oto nadchodzi dzień palący jak piec. A ponieważ wszyscy pyszni i wszyscy wyrządzający krzywdę będą słomą - spali ich ten nadchodzący dzień, mówi Jahwe zastępów. Spali ich tak, że nie zostawi po nich ani korzenia, ani gałązki.

A dla was czczących moje imię wzejdzie słońce sprawiedliwości i uzdrowienie w jego promieniach" $(3,18-20)$.

Podobne proroctwo znajdujemy w Księdze Izajasza:

„Swiatłość Izraela stanie się ogniem, a Swięty Jego - płomieniem. Pożre on i pochłonie jego ciernie i jego głogi w jednym dniu” $(10,17)$.

\section{Teksty Nowego Testamentu 55}

a) Narzçdzia wykonujące wyroki sądu Bożego

W Apokalipsie „ogień” jest jednym z prodromów paruzji - narzędziem już obecnie nadchodzącego gniewu Bożego względem niepokutu-

53 66, 14-16; por. $M l 3,19$ i $E z \quad 38,22$.

54 66, 24; por. 34,10 oraz Jdt 16, 17; Syr 31-9.

55 Pomijamy przenośnie z $M k$ 9, 49 - gdzie „ogień” oznacza cierpienia, którymi ma być „osolony" uczeń Chrystusa (J. Schmid, Das Evangelium nach Markus, Regensburg 1955, 183), oraz z $€ k 12,49$ - gdzie „ogien” jest symbolem niezgody (tenże, Das Evangelium nach Lukas, Regensburg 1955, 225). 
jących grzeszników $(8,7)$ - odpowiednikiem siódmej plagi egipskiej (Wj 9, 24). Ogniem tym włada jeden $\mathrm{z}$ aniołów (Ap 14, 18). Uzurpatorem właçzy riad ogniem jest „fałszywy prorok" - człowiek będący na usługach Szatana (13, 13 - por. 2 Tes 2, 3. 4. 9). W przeważającej jednak ilości wypadków ogień w NT ukazuje się jako narzędzie wykonujące wyroki sądu ostatecznego. Już Jan Chrzciciel mówi o Mesjaszu jako o kimś, kto ,będzie chrzcił Duchem Swiętym i ogniem” (Mt 3, 11; Łk 3, 16). Zanurzenie $w$ ogniu oznacza tu sąd ostateczny ${ }^{56}$. Jan Chrzciciel mówi tu o sytuacji człowieka, którą Paweł scharakteryzuje kiedyś w sposób następujący:

„Tak jak ktoś na tym fundamencie (którym jest Chrystus) buduje ze złota, ze srebra, z drogich kamieni, z drzewa, z trawy lub ze słomy tak też jawne się stanie dzieło każdego człowieka: odsłoni je dzień Pański. Okaże się bowiem w ogniu, który je wypróbuje, jakie jest" (1 Kor 3, 12; por. 12, 19).

Jan Chrzciciel przedstawia tę prawdę ponadto $\mathrm{w}$ obrazie palenia nieurodzajnych drzew (Mt 3, 10 par.), a Jezus - w obrazach palenia plew (Mt 3, 12), ostów $(13,40)$ i bezowocnej, uschłej latorośli $(J 15,6)$. Podobnie rzecz ujmuje List do Hebrajczyków: kto dobrowolnie grzeszy po nawróceniu - czeka go ,sąd i żar ognia, który ma pochłonąć przeciwników. (...) Bo nasz Bóg jest ogniem trawiącym ${ }^{57}$.

Gdzie indziej tenże List — jak już widzieliśmy — z ,płomieniami ognia" identyfikuje aniołów $(1,7)$.

b) Przyczyna męki wiecznego potępienia

W apokaliptyce NT ,piekło ogniste” (Mt 5, 22) i „piec ognisty” $(13,42.50)$ są przedłużeniem ognia sądu ostatecznego. Rzeczywistość, która kryje się pod terminem „ogień” - występującym w tekstach mówiących o karze potępienia zamiennie z terminem „ciemnośc”" (skótos) ${ }^{58}$ to przeciwstawieństwo wszystkiego, co kryje się pod określeniami: jasność, życie, Królestwo ${ }^{59}$.

Ogień potępienia to „ogień wieczny” ( $M t$ 18, 8; 25, 41), „ogień nie do ugaszenia" (Mk 9, 45; Mt 3, 12; Łk 3, 17).

Według Jud 7 plastycznym przykładem ognia piekielnego jest wspomniany już ogień, który pożarł mieszkańców Sodomy i Gomory. Opis ich kaźni leży również u podstawy opisów piekła przedstawianych przez Apokalipsę (19, 20; 20, 10-15; 21, 8).

c) Znak majestatu Chrystusa, Ducha Swiętego, aniołów

56 H. Schürmann, Das Lukasevangelium, w: Herders Theol. Komm. zum NT, Freiburg-Basel-Wien 1969, 3, 1, 174-177.

57 12, 29; Pwt 4, 24; por. Ap 20, 9; 2 P 3, 7. 10.

58 Mt 8,$12 ; 22,13 ; 25,30$.

${ }^{59}$ Mt 13, 42;18, $8 \mathrm{n} ; 25,41 ; M k$ 9, 43-47. 
Jak w ST „płonący ogień” był znakiem majestatu objawiającego się Boga Jahwe - tak w NT jest on znakiem boskiego majestatu Chrystusa: w Apokalipsie - we wstępnej wizji św. Jana - przymiot ten, przypisywany przez $D n$ 7, 10 oraz $E z$ 43, 2 Bogu - przypisywany jest Synowi Człowieczemu:

„Ujrzałem pośród świeczników kogoś podobnego do Syna Człowieczego, obleczonego w szatę sięgającą do stóp i przepasanego na piersiach złotym pasem. Głowa Jego i włosy białe jak biała wełna, jak śnieg, a oczy Jego niby płomień ognia. Stopy Jego podobne do cennego kruszcu, jakby w piecu rozżarzonego (...), a Jego wygląd jak słońce, kiedy jaśnieje w swej mocy" (1, 13-16).

„Ogień” jest w NT również znakiem szczególnej obecności Ducha Swiętego: podczas Jego zstąpienia w dniu Pięćdziesiątnicy ukazały się „języki podobne do ognia” ( $D z 2,3)$. Obraz ten musiał od razu kojarzyć fakt zesłania Ducha Swiętego z faktami teofanii ST.

Ten sam „ogień" jest przymiotem uczestniczących w chwale Boga aniołów (zob. wyżej), jest także przymiotem elementów „nowego stworzenia”: widziane przez Jana ,jakby morze szklane” jest „pomieszane z ogniem" $(15,2)$, a równocześnie ,podobne do kryształu” $(4,6)$.

\section{W N I O S K I}

W kontekście „dnia gniewu” obraz zstępowania Chrystusa „w płonącym ogniu" wskazuje na następujące prawdy teologiczne: Chrystus przyjdzie jako Kýrios - równy Bogu z teofanii ST, pełen nieskończonej potęgi. Wobec zatwardziałych grzeszników Jego chwała będzie rzeczywistością, która spowoduje ich zatratę: określenia „chwała Pańska” i „płomień ognia" są w tym wypadku synonimami. Kara potępionych będzie wieczna.

Natomiast w kontekście „dnia zbawienia” obraz ten mówi, że Chrystus przychodząc jako Kýrios zabierze, porwie $\mathrm{ku}$ sobie tych ludzi, w których ma upodobanie. Dla uciśnionych nadejdzie moment odpoczynku. Rzeczywistość, która ,spali wszystkich pysznych i tych, którzy wyrządzają krzywdę" dla "sprawiedliwych, czczących imię Boże” będzie „słońcem sprawiedliwości - i uzdrowieniem w jego promieniach" (Ml 3, 18-20).

Istnieją ponadto możliwości identyfikacji zwrotu „Pan objawi się w płonącym ogniu” z określeniami: ,przyjdzie w Duchu Bożym”, „z mocą Ducha Swiętego". 
III. ŻYWI - WRAZ Z TYMI, KTÓRZY UMARLI I ZMARTWYCHWSTALI ZOSTANA PORWANI NA SPOTKANIE PANA „W OBEOKACH”, „W PRZESTWORZA" (1 Tes 4, 7)

\section{A. Obłoki}

\section{Teksty Starego Testamentu}

a) Opisy poetyckie

Obłoki ${ }^{60}$, które odgrywają dużą rolę w starożytnej mitologii pogańskiej ${ }^{61}$, w opisach poetyckich $S T$ są tworzywem literackim służącym do ukazania prawdy o tym, że Bóg jest kimś wyższym ponad wszelkie stworzenie. W Pieśni Debory chmury spływają deszczem, ponieważ przechodził Jahwe, Bóg Izraela $(S d z 5,4 \mathrm{n})$. Gdzie indziej chmury-obłoki ukazywane są jako Jego mieszkanie (np. $2 S m$ 22, 12), jako Jego rydwan (Iz 19, 1; Ps 103[104], 3), lub jako podstawa Jego nóg ( $\mathrm{Na} \mathrm{1,3).}$

b) Opisy teofanii

Obecność Boga podczas wyjścia z Egiptu widoczna jest w obozie Izraela dzięki zjawisku, które nazwane jest „słup obłoku”. Ukazuje ono kierunek marszu ( $W j$ 13, $21 \mathrm{n}$ ), oddziela ich od Egipcjan — osłania przed napaściami wroga $(14,19 \mathrm{nn})$. Słup obłoku towarzyszy Izraelitom podczas całej ich wędrówki przez pustynię ( $L b 14,14)$; zstępuje na namiot spotkania, gdy Bóg rozmawia z Mojżeszem (Wj 33, 9 n; 40, 34; Pwt 31, 15).

Gdy jednak późniejsze pisma mówią o obłoku ${ }^{62}$ - najczęściej nawiązują do objawienia się Boga ,w gęstym obłoku, wśród grzmotów i błyskawic" na górze Synaj (Wj 19, 16; 24, 15 nn; Pwt 5, 19). Obłok ten w połączeniu z ,płomieniem ognia” — nazywany jest „,chwałą Jahwe” ${ }^{63}$.

c) Teksty eschatologiczne

W eschatologicznych tekstach proroków „obłok” jest częstym elementem scenariusza ,dnia Jahwe" ${ }^{64}$. W takiej też roli pojawiają się obłoki w cytowanym szereg razy przez $N T$ tekście $D n$ 7, 13: „Patrzyłem w widzeniu nocnym, a oto nadchodził $\mathrm{z}^{65}$ obłokami niebieskimi jakby Syn Człowieczy" 66 .

60 Hebr. 'ānañ, gr. nephele.

61 Zob. A. Oepke, ThWNT 4, 906.

62 Np. Ps 76 [77], 18; 77 [78], 14; 98 [99], 7; 104 [105], 39.

$63 \mathrm{Iz} 4$, 5; por. $2 \mathrm{Mch} 2,8 ; 1 \mathrm{Krl} 8,11 ; 2 \mathrm{Krn} 6,14$.

64 So 1, 16; Jl 2, 2; Ez 30, 3; 24, 12; 38, 9. Por. Ps 96 [97], 2; $M d r$ 5, 21; 2 Mch 2, 8.

65 Tekst Teodocjana: metá; LXX: epí. Stąd też różnice w NT.

66 Tekst ten stoi u podstawy częstych wypowiedzi literatury judaistycznej pozakanonicznej, które nieustannie powtarzają - niby refren - że Mesjasz przyjdzie "z obłokami niebieskimi" (np. $4 \mathrm{Ezd}$ 13, 1; inne teksty - zob. Billerbeck $1,956)$. 
Skoro jednak w 1 Tes 4, 17 chodzi o ,pporwanie w obłokach" l u$\mathrm{dzi}$ - na specjalną uwagę zasługuje tekst $\mathrm{Iz}$ 60,1-4. 8. Jest on częścią składową wielkiego poematu eschatologicznego, mówiącego o przyszłej chwale Jeruzalem:

„Powstań, świeć, Jeruzalem! Bo przyszło twoje światło

i chwała Jahwe rozbłysła nad tobą.

Bo oto ciemność okrywa ziemię

i gęsty mrok spowija ludy -

a ponad tobą jaśnieje Jahwe

i Jego chwała jawi się nad tobą!

I pójdą narody do twego światła -

królowie do blasku twojego wschodu.

Podnieś twe oczy wokoło i popatrz:

ci wszyscy zebrani zdążają do ciebie,

twoi synowie przychodzą z daleka -

na rękach niesione twe córy!

Kto to są ci, co lecą jak chmury

i jak gołębie do swego gołębnika?"

Mimo, że odpowiedź na postawione pytanie znajdujemy w wierszu następnym -

To statki przywożące twych synów z daleka!

- tradycja żydowska przy komentowaniu tego miejsca powraca nieustannie do wizji chmur, obłoków, a nie do zwykłych statków. I tak np. rabin Lewi (ok. 300 r. n. e.) wyjaśniał:

„Jeruzalem będzie wtedy miastem wielkim jak ziemia cała, a ziemia Izraela wielka jak świat cały. A jak się stanie, że synowie Izraela (...) przyjdą z krańców świata? - Zstąpią obłoki i zaniosą ich: zaniosą do Jeruzalem. O tym właśnie myśli prorok, gdy pyta: „Kto są ci, co lecą jak chmury i jak gołębie do swego gołębnika" ${ }^{67}$.

\section{Teksty Nowego Testamentu}

a) Reminiscencje teofanii Starego Testamentu

Wspomnienie obłoku, „pod którym pozostawali” Izraelici podczas wyjścia z Egiptu i podczas wędrówki przez pustynię, obłoku, „w którym zostali zanurzeni" znajdujemy w 1 Kor 10, 1 n. "Zanurzenie w obłoku" ukazywane jest tutaj jako moment rzeczywistego spotkania z Bogiem ${ }^{68}$. Reminiscencją tych samych wydarzeń opisanych w Księdze Wyjścia jest prawdopodobnie także szata literacka wizji ,potężnego anioła zstępującego z nieba, obleczonego w chmurę" w Apokalipsie $(10,1$; por. Wj $13,21)$.

67 Tamże 3, $635 \mathrm{n}$.

68 A. Oepke, ThWNT 4, 910. 
b) Opis Przemienienia Pańskiego: Mt 17, 5; Mk 9, 7; Łk 9, 34.

Markowy zwrot „zjawił się obłok ${ }^{69}$ osłaniający ich” jest jakby echem wydarzeń opisanych w $W j 24,15 \mathrm{nn} ; 40,35$ oraz $1 \mathrm{Krl}$ 8, 11. Autôิs wskazuje najprawdopodobniej na Jezusa ${ }^{70}$ wraz z Eliaszem i Mojżeszem. To ich ${ }^{71}$ osłonił obłok, a do uczniów doszedł głos ,z tego obłoku”. Toteż - podobnie jak świadkowie teofanii w czasach starotestamentalnych ${ }^{72}$ - uczniowie ,zlękli się" ( $M t$, $\pm k$ ), ,upadli na twarz i bardzo się zlękli" (Mt).

Osłonięcie obłokiem wskazuje tutaj na ścisłą przynależność Jezusa wraz z Eliaszem i Mojżeszem do Boga (por. Ps 26[27], 5). Jest ono również - jako odpowiedź na słowa Piotra (Mt 17, 4 par.) - wymowną wskazówką, że mieszkaniem odpowiednim dla Tego, za którym Apostołowie idą, dla Jezusa, nie są zwykłe namioty, lecz namiot z obłoku namiot odpowiedni dla Boga (por. Ps 17[18], 12 n). Osłonięcie obłokiem jest tutaj także znakiem wtargnięcia majestatu i zbawczych mocy Boga w ostateczne dzieje ludzkości i świata ${ }^{73}$.

c) Opis Wniebowstąpienia: $D z 1,9$.

W Dziejach Łukasz uzupełnia swój pierwotny opis rozstania się uczniów z Panem $\left(£ k\right.$ 24, 51) ${ }^{74} \mathrm{w}$ sposób następujący: „uniósł się w ich obecności w górę i obłok zabrał Go im sprzed oczu”. „A oni wpatrywali się w Niego, jak wstępował do nieba" (1, 9-10). W opisie tym passivum theologicum epërthè wskazuje na inicjatywę Ojca ${ }^{75}$ - to On unosi Jezusa do nieba. Zjawiskiem towarzyszącym temu wydarzeniu jest obłok, który wskazuje świadkom wniebowstąpienia (i tym, którzy czytają relację Łukasza), że umiłowany Syn Boży wstępujący na prawicę Bożą obdarzony jest tą samą chwałą, którą ma Ojciec (por. $J$ 17, 5. 10).

Według P. Benoit Łukaszowy opis Wniebowstąpienia z $D z$ 1, 9-11 jest formą kerygmatu dotyczącego bezpośrednio paruzji Chrystusa. Tradycyjny symbol obłoku ,zapowiada obłok eschatologiczny, na którym powróci Chrystus w chwili paruzji. Przedstawienie Jezusa unoszącego się do nieba na obłoku ma na celu wywołanie skojarzeń z zapowiedzianym Jego majestatycznym powrotem na obłoku w dniu paruzji. Wskazuje na to wyraźnie głos tłumaczących to wydarzenie aniołów: 'Ten

69 „Obłok świetlisty” wg $M t$.

70 Kodeks syrs sugeruje lekcję autō - jedynie słuszną wg J. Wellhausena. Kodeks 1604 z Góry Athos ma autón (u $モ k$ ).

71 A. Oepke, ThWNT 4, 911. H. Schürmann dodaje: ,aber ebenso gewiss auch die drei Jünger" (Das Lukasevangelium, dz. cyt., 561).

72 Rdz 26,14;28,17;Wj 3,$5 ; S d z 6,22 \mathrm{n}$.

73 Wj 16,10;19;9;24, 15. 18;33, 9;40, 34n; Kpz 16, 2; Lb 11, 25; $1 \mathrm{Krl}$ 8, 10n; 2 Mch 2, 8.

${ }_{74}$,Kiedy ich błogosławił, rozstał się z nimi i został uniesiony do nieba". Por. Mk 16, 19 i 1 Tm 3, 16.

75 M. Zerwick, Graecitas biblica..., dz. cyt., § 236. 
Jezus wzięty od was do nieba, przyjdzie tak samo, jak widzieliście Go wstępującego do nieba'" 76 .

d) Teksty eschatologiczne

Symbolika obłoku w tekstach eschatologicznych NT jest dokładną kontynuacją symboliki starotestamentalnej, pokrywa się także z symboliką obłoku w omawianych dotychczas tekstach $N T$ : obłok jest manifestacją chwały i mocy Boga. Nowość, jaką niosą teksty eschatologiczne $N T$ polega na tym, że obłok będący dotąd znakiem chwały Jahwe (ST), chwały Ojca $(N T)$, teraz staje się zjawiskiem towarzyszącym samemu Chrystusowi-Kyriosowi. Tekstem najważniejszym jest tutaj stwierdzenie samego Jezusa wobec Wysokiej Rady. Zapytany przez najwyższego kapłana „Czy ty jesteś Mesjasz, Syn Błogosławionego?” Jezus odpowiada: „Ja jestem. Ujrzycie Syna Człowieczego siedzącego po prawicy Wszechmogącego (tês dynámeōs) i nadchodzącego z obłokami niebieskimi" (Mk 14, 62) ${ }^{77}$. To zestawienie dwu tekstów mesjańskich - Ps 109[110], 1 i $\operatorname{Dn} 7,13$ - które Jezus odniósł do siebie, zabrzmiało wobec Wysokiej Rady jak bluźnierstwo. Najwyższy kapłan rozdarł szaty: Jezus będąc człowiekiem czynił siebie Bogiem (por. $J$ 10, 33) - rzeczywistości związane z symbolem obłoku przypisywał sobie.

Obłoki jako symbol majestatu i boskości Chrystusa pojawiają się również w tekstach ,apokalipsy synoptycznej" (Mt 24, 30; Mk 13, 26; Łk 21, 27): Jezus nazywa siebie Synem Człowieczym (Dn 7, 13) i zapowiada swoje przyjście „na obłokach niebieskich" (Mt), „w obłokach” $(M k)$, „w obłoku” (Ek).

Tak też widzi chwalebnego Chrystusa Wizjoner z Apokalipsy: „Ujrzałem, a oto biały obłok, a na obłoku siedzący - podobny do Syna Człowieczego. Miał złoty wieniec na głowie, a w ręku ostry sierp" $(14,14)$. Przymiotnik „,biały”, określający „,kolor” obłoku jest w tym tekście ${ }^{78}$ właściwą tekstom eschatologicznym daleko posuniętą konkretyzacją tego, co jest treścią bardziej abstrakcyjnego określenia „chwała - dóxa”.

\section{B. Przestworza}

\section{Literatura pozabiblijna}

Ho aèr uważany był w starożytności za jeden z zasadniczych elementów składowych kosmosu - obok ognia i wody. Oznacza zatem tyle, co powietrze. Równocześnie termin ten ma znaczenie „,przestworza”, ,,atmosfera". W języku religijnym Hellenów przestworza te są nie tylko przestrzenią, po której żeglują chmury i latają ptaki, lecz jest przestrzenią

76 L'Ascension, w: Exégèse et Théologie, Paris 1961, 1, $406 \mathrm{n}$.

77 Mk cytuje Dn 7, 13 wg tekstu Teodocjana. Mt 26, 24 ma epi wg LXX. Łk 22, 69 nawiązuje do $D n$ jedynie przez podanie tytułu „Syn Człowieczy”.

78 Por. 2,$17 ; 19,11 ; 20,11$. 
zamieszkałą przez niiedoskonałe duchy - w odróżnieniu od przestrzeni zwanej aithèr, przestrzeni czystej, będącej mieszkaniem herosów, bogów, demiurga.

W rabinistyce żydowskiej atmosfera jest domeną duchów złych, zbuntowanych ${ }^{79}$.

\section{Teksty Starego Testamentu}

W ST termin aèr ${ }^{80}$ oznacza powietrze, którym się oddycha ( $M d r 2,3$; $13,2,15,5)$, które pruje strzała $(5,12)$, w którym fruwają ptaki $(5,11)$. $2 M c h$ przekazuje wiadomość o tajemniczym ukazywaniu się w powietrzu, czy z powietrza (dià tôn aérōn) jeźdźców ubranych w szaty haftowane złotem. Izraelici modlą się, żeby to zjawisko było zapowiedzią wydarzeń pomyślnych $(5,2)$.

W hymnie dziękczynnym Dawida z $2 S m$ 22, 12 powiedziane jest, że en nephélais aéros przychodzi zbawiający Jahwe, Bóg (por. 17, 11).

\section{Teksty Nowego Testamentu}

W przysłowiowych powiedzeniach św. Pawła z 1 Kor 9, 26 i 14, 9 oraz z $D z$ 22, 23 aèr oznacza powietrze.

Znaczenie ,przestworza" ma ten termin w Ap 9, 2 i 16, 17. Według Ef 2, 2 władcą przestworzy jest Szatan, nazwany w tym tekście árchōn tês exousías toû aéros.

\section{W N I O S K I}

Porwanie ,w przestworza" jest jak się wydaje określeniem pleonastycznym w stosunku do określenia „w obłokach”. Nie wnosi chyba żadnej nowej treści. Jest po prostu odpowiednikiem zwrotu z $2 \mathrm{Sm}$ 22, 12 - en nephélais aéros.

Obraz porywania ludzi na spotkanie Pana „w obłokach, w przestworza" sugeruje następujące treści teologiczne: zbawieni zostaną na zawsze uwolnieni od ataków Wroga; wejdą do mieszkania Boga - wejdą w zupełnie nowy - niedostępny dotąd ludziom - wymiar egzystencji, właściwy samemu Bogu; wejdą do swojej właściwej ojczyzny — do ,namiotu" odpowiedniego dla przyjaciół Jezusa Chrystusa; będą odtąd zawsze z Bogiem i będą należeć do Boga na wzór Jego Syna, Jezusa Chrystusa; wszyscy zostaną niejako ubóstwieni — „otrzymają na własność chwałę Pana naszego Jezusa Chrystusa" (2 Tes 2, 14).

79 W. Bauer, dz. cyt.; W. Foerster, ThWNT 1, 165.

80 Pomijamy tekst $M d r$ 2, 7, w którym LXX ma slowo aèr zamiast éar „wiosna” (Aquila). 
IV. BEZBOŻNIKA PAN JEZUS ZMIECIE PRECZ „TCHNIENIEM UST SWOICH” (2 Tes 2, 8)

1. „Tchnienie ust Pana” w tekstach Starego Testamentu

a) Symbol mocy Boga Stwórcy

Jedyny w ST dokładny odpowiednik określenia ,tchnienie ust Pana” z 2 Tes 2, 8 znajdujemy w Ps 33 (32), 6:

Przez słowo Pana powstały niebiosa

i wszystkie ich zastępy przez tchnienie ust Jego

(tō pneúmati tổ stómatos autoú)".

W tekście tym, nawiązującym do $R d z$ 1, 2 nn. "tchnienie ust Pana" jest symbolem stwórczej potęgi wszechmogącego Boga.

b) Symbol mocy Boga, który swój gniew kieruje przeciw grzesznikom

Tekst Księgi Joba mówiąc o sprawiedliwości Boga stwierdza, że złoczyńca „upada pod tchnieniem Jego oburzenia - apó pneúmatos orgês autô̂" (4, $8 \mathrm{n})$. Tekst ten podkreśla więc fakt absolutnej przewagi Boga nad mocą zła.

Podobny wydźwięk ma tekst z Księgi Mądrości, w którym mowa jest o tym, że Egipcjanie - wrogowie Izraela - „paść mogli od jednego podmuchu (hení pneúmati) — zmieceni tchnieniem mocy Bożej (hypô pneúmatos dynámeōs sou)".

Zwrotem „tchnienie ust, tchnienie warg Pana” posługuje się tė̇ Iz 11, 4 celem uzmysłowienia czytelnikowi potęgi Boga, który z najzupełniejszą łatwością może ukarać wszelką bezbożność. Warto dodać, że ten tekst Izajasza występuje w kontekście, w którym mowa jest nie tyle o zwyczajnym, ludzkim tchnieniu ust Potomka Jessego, co o Tchnieniu Bożym, o Duchu Jahwe $(11,2)$ mającym zstąpić na oczekiwanego Mesjasza - napełnić Go wszystkimi swoimi darami. Autorowie Ksiąg NT, postępując drogą wyraźnie wytkniętą przez Jezusa, widzą w określeniach Izajasza ,Tchnienie-Duch Pański” zapowiedź objawienia się i specjalnego działania w czasach mesjańskich Trzeciej Osoby Trójcy Swiętej - Ducha Swiętego ${ }^{81}$.

\section{Teksty Nowego Testamentu}

Poza tekstem z 2 Tes 2, 8 zwrot ,tchnienie ust Pana" w NT nie występuje. Podobnego jednak zwrotu używa autor Apokalipsy; przekazuje wizję Jeźdźca na białym koniu, którego imię „,Słowo Boże”, ,a z ust Jego wychodzi ostry miecz, by nim uderzył narody. On paść je będzie laską żelazną. Tłoczy On prasę wina zapalczywego gniewu wszechmogącego Boga" (19, 11-15). Ostry miecz wychodzący z ust Pana - okréśle-

81 Zob. Mt 3, $15 \mathrm{n} ;$ Ek 4, 1. $18 \mathrm{n} ; J$ 1, 33; 14, $16 \mathrm{n} ; D z 1,8 ; R z 5,5$ n. 
nie, które uważamy za bliskie określeniu „tchnienie ust Pana” — jest tutaj, jak wynika z kontekstu, symbolem mowy Chrystusa. Jest symbolem Jego słowa, które jest „ostrzejsze niż wszelki miecz obosieczny” (Hbr 4, 12) - słowo, które osądzi w dniu ostatecznym wszystkich, którzy je słuchali, lecz go nie wypełnili (por. $J 12,47 \mathrm{n}$ ).

\section{W N I OS K I}

„Tchnienie ust Pana" to określenie będące w ST symbolem bądź to stwórczej potęgi Boga - bądź to symbolem absolutnej Jego przewagi nad mocami Zła. To drugie znaczenie jest́ charakterystyczne dla tekstów eschatologicznych. Jedyny w NT - i to dość daleki - odpowiednik tego określenia, jaki znajdujemy w Apokalipsie (,ostry miecz wychodzący z ust" Pana), jest symbolem wszechmocy Jego słowa w dniu zatraty bezbożników.

A zatem występujące w kontekście „dnia gniewu” określenie „Pan Jezus zmiecie Bezbożnika tchnieniem ust swoich" mówi o tym, że przytłaczająca chrześcijan ogromna moc Bezbożnika jest zupełnie niczym w zestawieniu z mocą Chrystusa-Kyriosa.

Możliwa jest ponadto identyfikacja treści określenia ,tchnienie ust Pana” z treścią określenia „moc Ducha Swiętego”.

\section{REFLEKSJE KOÑCOWE}

Przeglądając wnioski - podawane po dokonywanej kolejno analizie znaczenia terminów rozkaz, głos Archanioła, głos traby Bożej, niebo, aniołowie mocy Pana, płonacy ogien, obłoki, przestworza, tchnienie ust Pana — odnosimy wrażenie, że te elementy apokaliptycznej szaty literackiej opisów paruzji Chrystusa z Listów do Tesaloniczan zostały użyte jako swojego rodzaju hasła wywoławcze. Wszystkie te symbole musiały wywoływać w umysłach i sercach pierwotnych adresatów tych Listów żywy od dźwię k, szereg koniecznych skojarzeń. Zespoły tych skojarzeń prowadziły do lepszego utrwalenia w świadomości odbiorców Listów przekazywanych prawd objawionych.

Można o tym powiedzieć inaczej: chcą c by c zytelnicy przekazywaną prawdę ujrzeli wyraźniej, żeby ją ujrzeli z wielu stron - A utor eksponuje tę prawdę przez umieszczenie jej w oprawie wymownych, apokaliptycz$\mathrm{nych}$ symboli. Posługując się zaś językiem zaczerpniętym z teorii przekazywania myśli można powiedzieć, że a utor posługuje się metodą mówienia niejako pleonastycznego. Współczesna nauka o metodach przekazywania myśli podkreśla fakt, że treść podawana przez uczącego tylko jeden raz - dociera do świadomości słu- 
chaczy tylko wyjątkowo. Trzeba ją powtarzać szereg razy i to w rozmaitych wersjach, żeby dotarładowszystkich i utrwalała się w umysłach na stałe, w sposób niezatarty ${ }^{82}$.

Uważa się powszechnie, że wydźwięk tekstów apokaliptycznych $\mathrm{z}$ całą ich barwną apokaliptyczną symboliką - jest zdecydowanie $\mathrm{k}$ a $\mathrm{t}$ astroficzny. Wydźwięk natomiast tekstów traktujących o ostatniej fazie Królestwa Bożego na ziemi (a więc Jezusowych przypowieści), oraz wydźwięk tekstów doktrynalnych mówiących o końcu misji Kościoła (a więc tekstów $\mathrm{z}$ Listów Więziennych św. Pawła) jest zdecydowanie triumfalny.

Dokonana próba odszukania właściwego sensu apokaliptycznej szaty literackiej opisów paruzji Chrystusa z Listów do Tesaloniczan rzuca pomost między tymi dwoma skrajnymi opiniami. Okazuje się, że istnieje niemal pełna harmonia treści teologicznej zawartej we wszystkich tych tekstach. Mamy tu do czynienia jedynie z różnymi rodzajami literackimi, które należy interpretować zgodnie $\mathrm{z}$ intencjami Autorów.

Gdy przyjrzymy się całości obrazu dnia paruzji Chrystusa, jaki zarysowują teksty $\mathrm{z}$ Listów do Tesaloniczan, gdy prawidłowo odczytamy jego treść teologiczną, jesteśmy uderzeni tchnącym z tego obrazu optymizmem: zbliżający się „dzień Pański” ma być dniem ostatecznego wypełnienia się zbawczej misji Syna Bożego, Jezusa Chrystusa i założonego przezeń Kościoła. Toteż jest jakimś tragicznym nieporozumieniem lęk przed ,końcem świata”, jaki zauważamy wśród chrześcijan naszych czasów.

Nauki pism Starego Testamentu o ,dniu Jahwe”, a następnie w jeszcze większym stopniu - nauki samego Jezusa o "owym dniu" Jego chwalebnej paruzji splecione w Listach do Tesaloniczan przy pomocy apokaliptycznych symboli w jedną, harmonijną całość, mają wydźwięk jednoznaczny. Zarówno to, co zostało w nich powiedziane wyraźnie, jak i to, co ukryte zostało pod symboliczną szatą literacką, wskazuje niezmiennie na fakt, że dzień paruzji Chrystusa będzie „dniem gniewu" jedynie dla tych ludzi, „którzy nie przyjęli miłości prawdy” (2 Tes 2, 10) - którzy obecnie "dopełniają miary swych grzechów" (1 Tes 2, 16). Natomiast dla chrześcijan ma to być prze-

82 Zob. np. J. Dollard, N. E. Miller, Osobowość i psychoterapia - analiza w terminach uczenia się, myślenia i kultury, Warszawa 1967, 32-63. 
cież „dzień zbawienia”, dzień uwielbienia - dzień, który otworzy nam możliwość ,przebywania z Panem już na zawsze” (1 Tes 4, 17).

\section{LE SCENARIO APOCALIPTIQUE DE L'AVENEMENT DU SEIGNEUR DANS $1-2$ AUX THESSALONICIENS}

\section{R E S M E}

INTRODUCTION. Le travail présent se propose de justifier l'emploi et d'exposer le sens des symboles apocaliptiques (kéleusma, phōnê archangélou, sálpinx theồ, ouranós, ángeloi dynámeōs Kyriou, pýr phlogós, nephélai, aēr, pneûma toû stómatos Kyriou) dont se sert l'auteur de deux Lettres aux Théssaloniciens en y décrivant la Parousie du Christ.

La PREMIEERE PARTIE présente le contexte dans lequel on rencontre ces symboles („Jour de colère”, „Jour de salut”) et montre qu'ils ne sont pas repris au milieu culturel grec mais proviennent de l'Écriture (controverse J. Dupont A. Deissmann, B. Rigaux et autres). C'est pourquoi leur lecture correcte suppose tout l'arrière-plan des couches successives de la tradition vétéro-testamentaire.

L'interprétation des symboles en cause relève donc des principes herméneutiques propres à l'apocalyptique biblique, c'est à dire:

a) on ne peut jamais prendre ces symboles à la lettre;

b) on ne peut pas oublier qu'il sont susceptibles de diverses interprétations et acceptions;

c) on doit tenir compte de leur transposition chrétienne quant au sens;

d) on doit toujours se rappeler qu'ils se rapportent au mystère proclamé et à venir: seule, cette venue rendra parfaitement clair ce qui reste encore caché.

La DEUXIEIME PARTIE est consacrée à l'analyse des ledits symboles dans les écrits de l'Ancien et du Nouveau Testament; celle-ci mène à leur interprétation dans 1-2 Thess.

I. La tournure: au signal - ̀̀ la voix de l'Archange, c'est à dire (sic!) à la voix de trompette de Dieu (1 Th 4, 16) forme un tout. Le premier membre est complété par le deuxième et le troisième. Il s'agit de la voix toute puissante du Christ-Kyrios (comp. In 5, 28). Elle s'adresse aux morts, aussi à ceux qui sont morts dans le péché - ce que le texte semble passer sous silence - et se rapporte à leur résurrection.

II. Les cieux d'où le Seigneur „se révèle" et „descend” (1 Th 1, 10; 4, 16; 2 Th 1,7) ne se rapporte pas à un lieu déterminé, mais signifie, comme on dirait aujourd'hui, la dimension transcendentale de l'existance divine, dimension toute autre que la nôtre mais en même temps absolument proche à chacun. Dans le contexte du „Jour de colère" la descente des cieux du Seigneur veut dire sa maîtrise absolue des forces du Mal, et dans le contexte du „Jour de salut" - que notre vraie patrie est déjà là (comp. Ph 3, 20).

La venue du Seigneur avec les anges de sa puissance (2 Th 1, 7) signifie la proximité de la rencontre de tout le genre humain avec Dieu, rencontre décisive 
pour l'éternité. C'est aussi le moment de la séparation entre justes et mauvais et l'éloignement des attaques de Satan. Les justes entreront dans la sphère de la liturgie céleste, les injustes seront livrés à la damnation.

La flamme brûlante de la Parousie $(2 T h 1,8)$ est synonime de la ,gloire de Yahvé"; elle amènera la perte des impies au ,Jour de colère" en même temps qu'elle glorifiera les élus au „Jour de salut” (comp. $M l$ 3, 18-20).

III. L’image des élus emportés sur les nuées dans les airs (1 Th 4, 17) à la rencontre du Seigneur suggère ce que dit la Révélation: les élus seront désormais à l'abri des attaques de l'ennemi, ils entreront dans une nouvelle dimension, celle de l'existence divine, ils entreront dans le ,tabernacle” préparé aux amis et frères de Jésus, ils seront glorifiés.

IV. L'affirmation que le Seigneur fera disparaître l'Impie par le souffle de sa bouche $(2 T h 2,8)$ indique la victoire sans retour du Christ-Kyrios sur le ,mystère de l'impiété". On peut y voir aussi un synonyme de la „force de l'Esprit Saint".

CONCLUSION. Les symboles apocalyptiques de la description de l'Avènement du Seigneur dans 1-2 Th sont autant de mots - évocateurs destinés à susciter chez les destinataires des Letters des as ociations correspondantes cu même des ensembles de celles-ci. L'auteur désire aider les Théssaloniciens à mieux assimiler la doctrine relative au second avènement $\mathrm{du}$ Christ.

Nous sommes done en présence d'une méthode didactique, bien connue aujourd'hui dans l'enseignement, celle du parler pléonastique. Le maître reprend à plusieurs fois et sous diverses approches la matière proposée de façon à ce qu'elle pénètre les esprits des auditeurs et s'y fixe de manière indélébile.

La connaissance des associations reliées aux symboles apocalyptiques nous permet aujourd'hui une meilleure intelligence des textes mentionnés. Car, à première vue, les textes apocalyptiques soit des Lettres aux Théssaloniciens, soit des Evangiles ou de l'Apocalypse de Saint Jean nous font penser que le ,Jour de Seigneur" est une effroyable catastrophe. Par contre les paraboles relatives à la dernière phase du Royaume des cieux ici-bas (Évangiles) et les textes qui se rapportent à la finale de la proclamation du salut par l'Église (Lettres de captivité) nous suggèrent que ce Jour est un jour de liesse et de $\mathrm{triomphe.}$

Or la lecture correcte des symboles apocalyptiques montre qu'en vérité ils jouent une fonction de pont entre ces deux interprétations extrêmes. Leur contenu théologique s'accorde pleinement ici et là. Tout ce qui y est dit expréssement, comme ce qui est présenté sous un revêtement littéraire, montre pareillement que la Parousie sera un „Jour de colère" uniquement pour ceux qui n'ont pas accueilli „l'amour de la vérité” (2 Th 2, 10) „mettant ainsi en tout temps le comble à leur péché" (1 Th 2, 16). Au contraire, pour ceux qui meurent „dans le Christ" ce sera le „J our d e salut" et de gloire lequel nous donnera d'ètre ,avec le Seigneur toujours" (1 Th 4, 17). 